\title{
Archipel
}

ARCHIPEL Études interdisciplinaires sur le monde insulindien

$89 \mid 2015$

Varia

\section{Sultans' Palaces and Museums in Indonesian Borneo : National Policies, Political Decentralization, Cultural Depatrimonization, Identity Relocalization, 1950-2010}

Musées et palais à Kalimantan: construction nationale, décentralisation politique, dépatrimonialisation culturelle et relocalisation identitaire (1950-2010)

\section{Bernard Sellato}

\section{(2) OpenEdition}

\section{Journals}

Electronic version

URL: http://journals.openedition.org/archipel/494

DOI: 10.4000/archipel.494

ISSN: 2104-3655

\section{Publisher}

Association Archipel

\section{Printed version}

Date of publication: 15 April 2015

Number of pages: 125-160

ISBN: 978-2-910513-72-6

ISSN: 0044-8613

\section{Electronic reference}

Bernard Sellato, "Sultans' Palaces and Museums in Indonesian Borneo : National Policies, Political Decentralization, Cultural Depatrimonization, Identity Relocalization, 1950-2010", Archipel [Online], 89 | 2015, Online since 15 June 2017, connection on 05 March 2021. URL: http://journals.openedition.org/ archipel/494 ; DOI: https://doi.org/10.4000/archipel.494 


\section{IDENTITÉS À BORNÉO}

BERNARD SELLATO ${ }^{l}$

\section{Sultans' Palaces and Museums in Indonesian Borneo: National Policies, Political Decentralization, Cultural Depatrimonization, Identity Relocalization, 1950-2010²}

After fighting an independence war in the 1940s and several armed rebellions in outer provinces in the 1950s, the unitary and centralized Indonesian state abolished the country's remaining kingdoms and seized their assets. From 1970 onward, in the framework of its sweeping nation-building policies and successive five-year development plans, it undertook the establishment of museums in all 26 provincial capital cities, a task completed by 1985 .

The sultans' confiscated palaces were turned into state museums, the collections of which derived in part from the palaces' collections. The patrimonized buildings themselves - the central topic of this essay, which does not concern itself with the details of their architectural features, possibly the topic of another paper-were viewed as part of the nation's architectural heritage, with their collections meant to represent regional cultures. Museums were then assumed to constitute tools both for preserving and developing these regional traditions and for modernizing and unifying the country, not to mention their increasingly important role as tourist destinations.

After providing succinct background information on the colonial and postcolonial history of Kalimantan (see fig. 1), this essay reviews the development

1. Centre Asie du Sud-Est (CASE), UMR 8170, CNRS/EHESS, Paris, France.

2. This is an expanded version of a paper given at the conference on "Cultural Tourism in East and South-East Asia: Perspectives and economic, political and identity stakes," organized by CEFURDS (Center for Urban and Development Studies, Ho Chi Minh City), CAPAS (Center for Asia and Pacific Studies, Academia Sinica, Taipei), Département d'Etudes Asiatiques (Université de Provence, Aix-en-Provence), IRSEA (Institute for Research on Southeast Asia, Marseille), and Maison Asie Pacifique (Université de Provence \& CNRS, Marseille), in Dalat, Vietnam, 3-5 January 2011. 


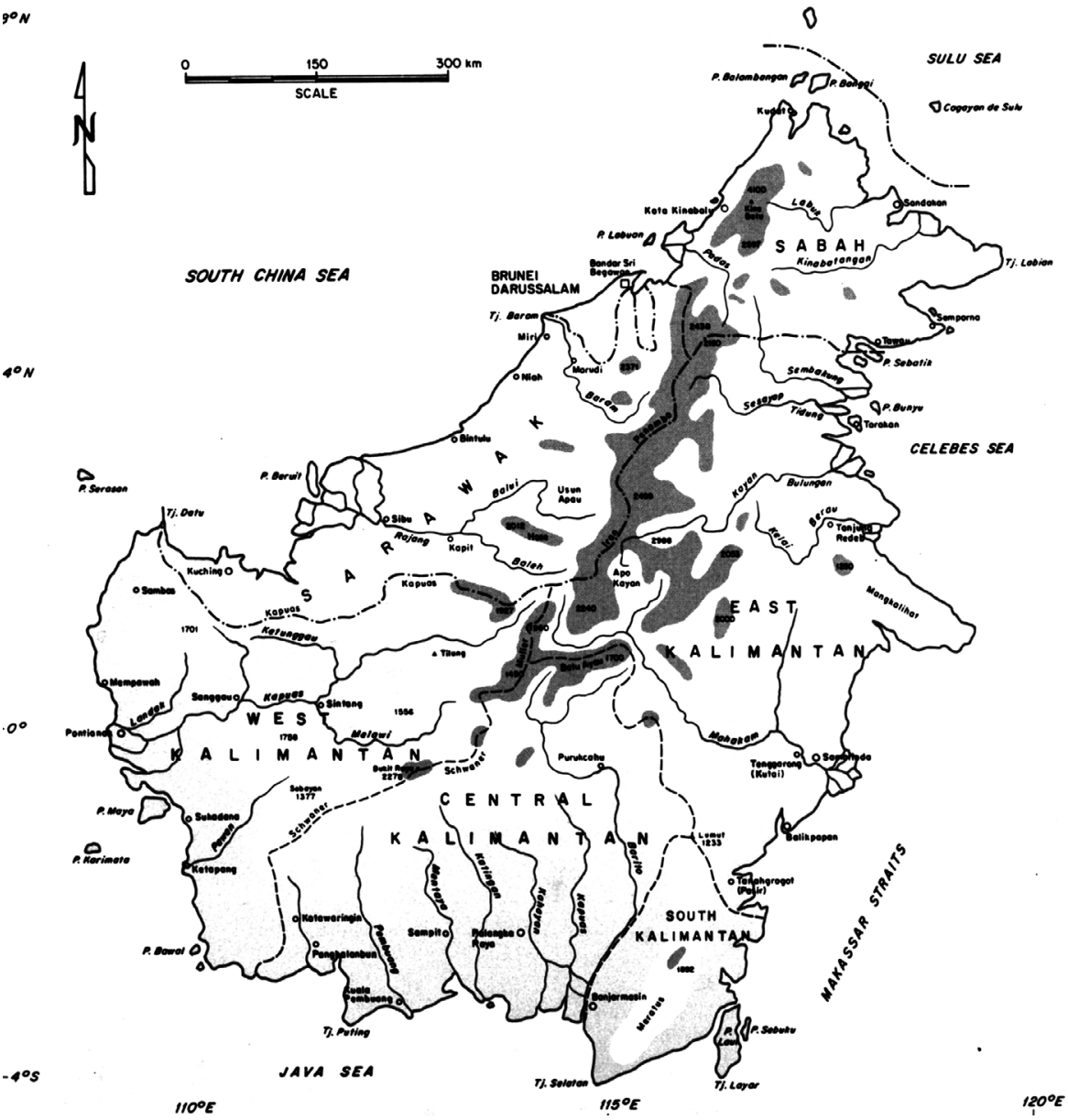

Fig. 1 - Map of Borneo. Location of places mentioned in the text.

of second-generation museums (state museums) in independent Indonesia, and the state's policies regarding culture and museums. It then focuses on the specific case of Kalimantan, during the New Order period (1965-1998) and after the rapid decentralization that followed the demise of President Soeharto's regime. Then the advent of a third generation of museums in the early $2000 \mathrm{~s}$ is described, as well as a process of depatrimonization of the palaces and their collections subsequent to the restoration of the former kingdoms. Finally, it briefly considers the future role of these palaces in the regions' cultures and increasingly lively political scenes, and discusses the "new museum" concept, meant to involve local communities, as applied to Kalimantan. 


\section{Kalimantan: historical framework in a nutshell}

In pre-colonial and colonial times, virtually all of Borneo's river basins were controlled by trading polities, whether powerful sultanates or petty polities, whose seats were located at river mouths and the confluences of major tributaries. Among some 300 such polities, small and large (see Hägerdal 2003, RAI 2012), in the territory that is now Indonesia, Kalimantan alone, up to the end of the nineteenth century, had over 25, forming a circular chain of relations of subordinates to overlords all around the island's coastline and a similar chain, with a hierarchy of subordination, along river axes between the coast and the far hinterland (see Sellato 2013).

During Dutch times, particularly in the $19^{\text {th }}$ and early $20^{\text {th }}$ centuries, some of these polities fought against Dutch control (e.g., Banjarmasin) and were obliterated, while others collaborated (e.g., Kutai) and were left, until the 1930s, with a semi-autonomous status (Zelfbesturen, Swapraja, or Special Region; see Van Klinken 2006, Cribb 2000, 2010). On the island's east coast, the Dutch discovered petroleum, and sultans' cooperation was secured through the payment of royalties.

In post-Independence times, after 1949, the unitary Indonesian state, focusing on nation building, waged wars against rebel provinces, which favored a federal state. This culminated, in the 1950s, in the abolition of most of the country's semi-autonomous sultanates (Yogyakarta being an exception) and the appropriation by the state of their assets, privileges, and revenue. The same policy of building an Indonesian nation was pursued during General Soeharto's stretched New Order, from the mid-1960s to the late 1990s, leaving little initiative to provinces, especially outside Java (regarding Kalimantan, see a discussion in Sellato n.d.; also, Sellato 1998).

When the New Order came to an end in the late 1990s and the Reformasi period began, a policy of decentralization (Otonomi Daerah, regional autonomy), initiated earlier, was fully implemented, devolving some political power and much economic autonomy to provinces and districts (also called regencies). With a sudden afflux of financial means from local revenue, especially to districts, a more localized identity emerged, or re-emerged, everywhere.

\section{A brief history of museums in indonesia}

While traditional societies in Indonesia, whether states or tribes, had long practiced the collecting and preserving of cultural artefacts in relation with local concepts of pusaka (cultural heritage with a valuable, spiritual, or sacred character; see Damais 1992, Kreps 2003, 2006, Guerreiro 2011, Njoto 2015, and below), Western ideas about museums and conservation of cultural artefacts were first expressed there in the mid-seventeenth century with the Dutch naturalist Georg Eberhard Rumpf's (Rumphius) Ambonese cabinet de curiosités (Amboinsche Rariteitkamer). In 1778, the Bataviaasch 
Genootschap van Kunsten en Wetenschappen (Batavian Society of Arts and Sciences) was established in Batavia (now Jakarta), on the initiative of Dutch scholars, complete with a library and museum - it was well cared for by Thomas Stamford Raffles, the lieutenant-governor of Java, during the short British interregnum of the early nineteenth century.

\section{From the Bataviaasch Genootschap to the Directorate of Museums ${ }^{3}$}

In 1862, the Batavian Society was housed in a new building, where it remained till after the country's independence. Around the turn of the twentieth century, some Javanese princes and regents began establishing their own private museums, as in Surakarta in 1890, Surabaya around 1900, and Mangkunegaran in 1918, to accommodate their pusaka articles, various collections, or local antiquities (see Njoto 2015). Starting in 1915 (or earlier?) and till 1941, the Dutch colonial government set up other museums, some of which were located outside of Java, in regions inhabited by demographically powerful ethnic communities with a robust regional cultural identity (Aceh, Batak, and Minangkabau in Sumatra, and Bali), and collections of objects from the Society were transferred there (DM 2011).

In 1925, as the Royal Batavian Society, it was reorganized as a center of "all cultural sciences" in Indonesia-i.e., "oriental studies," as they were then conceived - and contributed much to the study of Indonesian life and culture (UNESCO 1985). A law on cultural property, the Monumenten Ordonnantie (Monument Ordinance) No. 238, was enacted in 1931 (ICOM 2010).

Sixteen museums established by the Dutch were in existence on the eve of World War II (DM 2011) - none of which, apparently, was in Kalimantan (but see below) - or maybe as many as 24 to 26 by the end the war (Sutaarga 1990, cited in ICOM 2010; History 2014). Possibly not accounted for were several local museums that had, in the 1930s, been established, usually privately, by concerned civil servants and Christian missionaries-who had recognized the fading of indigenous material culture, "a gradual process of cultural impoverishment" (History 2014), as a detrimental consequence of colonization, as well as, probably, Islamization-but, praiseworthy as they were, such museums often lacked expertise and resources, and were often short lived (Rath 1997, History 2014).

After independence, in 1950, the Society became the Lembaga Kebudayaan Indonesia (Indonesian Cultural Institute). The state soon established cultural offices in several provinces (1952), then a Bagian Urusan Museum (Service of Museums, 1957), successively renamed Lembaga Museum-Museum Nasional, Direktorat Museum, and Direktorat Permuseuman in 1975 (DM 2011, History

3. Data for this section were compiled from the literature and various official sources: UNESCO 1973, 1985, ICOM 1976, 2010, Soemadio 1987a, DM 2011. 
2014). Meanwhile, in 1962, the old Batavian Society was handed over to the state, and its museum became the Museum Pusat (Central Museum, or National Museum), now considered one of Asia's oldest museums; the library attached to it, with its renowned collection of manuscripts, is now a part of the National Library in Jakarta.

As of late 2014, after various structural reshuffling episodes (see Kreps 2003, DM 2011), there is a Directorate of Conservation of Cultural Assets and Museums (Direktorat Pelestarian Cagar Budaya dan Permuseuman) under a Directorate-General of Culture (Direktorat Jenderal Kebudayaan), itself under the Ministry of Education and Culture (Kementerian Pendidikan dan Kebudayaan; Kemdikbud 2013), with "Tourism" having transferred to a another ministry. Military museums, it may be noted, are supervised by the Defense Ministry (History 2014).

Benefitting from the powerful economic impetus of the early 1970s, museum development gained momentum and the Directorate of Museums began a broad campaign to renovate some colonial monuments and upgrade the condition and numbers of provincial museums (Njoto 2015), the latter based on the European and American model, with professional staff trained in Western countries, and following the International Council of Museums' definitions and standard guidelines (Kreps 1994) - Indonesia joined ICOM in 1970 (Kreps 2003: 25). So, as early as in the first five-year plan (Pelita I, 1969/1970 to 1973/1974), the Directorate undertook the building and/or renovation of museums. Soon, in 1975, the "Beautiful Indonesia in Miniature Park" (Taman Mini Indonesia Indah, TMII), a theme park focused on regional architectural styles, was built in a Jakarta suburb to put the nation's cultural diversity on public display (see Guerreiro 2007; on provincial styles, see Sellato 1998).

By the end of Pelita III (1984), as many as 26 museums, one in each province's capital town, had been upgraded or established (to which a $27^{\text {th }}$ was added in Pelita VI in East Timor). In 1990, there were some 140 museums, either public or private, in the country (Kreps 1998: 6). And by 2000, there were 262 (Kreps 2003: 25), including one Museum Nasional (Jakarta), 26 Museum Negeri Provinsi (provincial state museums), four Museum Khusus (special museums, under the same Ministry), and 231 "other museums," unaffiliated to the Ministry (DM 2011). As of 2014, the number of provinces in Indonesia has soared to 34-although all probably do not yet have their own state museum, now called Museum Umum Provinsi (public provincial museum) — and Indonesia has almost 300 museums (Asosiasi 2013), of which some 80 are labelled as "state museums" (museum negeri; History 2014).

Historically, the dividing line between private and public museums seems to have been rather hazy. Since Indonesia's independence, a general trend has been for private museums to be taken over, for supervision, direct 
management, and funding, by state agencies, at varying administrative levels, in the same way that private schools, e.g., those founded and run by religious organizations, were progressively integrated into the state's standard educational system (dinegerikan). It may be assumed that scores of the "other museums" mentioned above benefitted, at provincial level, from some form of assistance, technical or financial, from state agencies.

In the course of time, the Directorate of Museums released various documents on legal and administrative aspects of the management of its museums (e.g., DM 1989, 2009c), as well as various "handbooks" or "directives" (pedoman), regularly updated, for use by provincial museums' heads and staffs (DM 1979/1980, Soemadio 1987b, DM 1989/1990, 1995, 1998, 2008). Altogether, although more recently established museums have already achieved higher standards, the increase in numbers of museums has yet to be matched by a progress in quality (History 2014).

\section{National Policies on Museums}

Following the abolition by the centralized state of almost all kingdoms and sultanates in Indonesia in the 1950s and 1960s, a number of the former rulers' palaces (keraton), taken over by the state, were turned into museums - likewise, minor local museums were also taken over by the state. As Rath (1997) noted, it was important for the state to, at the same time, appropriate the supernatural power - as well as the dynastic regalia - associated with the keraton, and consolidate state power over the regional culture (see also Taylor 1994b, Kreps 2003, Njoto 2015). This was the case of the palace of the sultan of Kutai-which became the Museum Mulawarman, the state museum of East Kalimantan - as well as of other palaces, such as those in Pontianak and Ternate.

The Indonesian state's cultural policy, from the start, was part and parcel of its all-encompassing nation-building policy. Much has been written about this, and it will not be elaborated on here. Regarding culture, the 1945 Constitution's Paragraph No. 32 stated that "the government will promote the Indonesian national culture", and clarified it as follows: "The national culture is the culture which arises as the fruit of the entire Indonesian people" (ICOM 2010). Regarding museums, as early as 1950, Ki Mohd. Amir Sutaarga stressed that the new nation's museums were thoroughly neglected, and called for their being put to use for social-educational purposes (DM 2011). Sutaarga (1928-2013), the first head of the Museum Nasional (1962-1975) and of the Directorate of Museums (1966-84), and the pioneer of a Museology curriculum at the University of Indonesia in Jakarta, was instrumental in defining Indonesia's ideological and political agenda regarding museums, as well as in establishing, by 1984, the country's 26 provincial state museums (Asosiasi 2013; see also Sutaarga 1957, 1977). Later on, several new laws were passed, including Law No. 5 of 1992, dealing with cultural property and meant to replace the 1931 Monument Ordinance (ICOM 2010). 
In the context of the New Order's imperious "Development"(Pembangunan) policies of the 1970s, legislators asserted that the "best features" (i.e., those in line with the national ideology) of regional cultures should be "preserved and developed," so that they could contribute to the emergence of an "Indonesian national culture", as per the nation's motto, "Unity in Diversity" (Bhinneka Tunggal Ika; see, e.g., Sellato n.d., Taylor 1994a, Kreps 2003, Hitchcock et al. 2010). Then, cultural development being viewed as inseparable from overall national social-economic development, museums were conceived of as both symbols of modernity and tools of modernization (modernisasi), and as participating in the nation's development through their role as nonformal educational institutions - apart from providing local communities with recreational outlets (Kreps, 1994, 1998). So, in the 1970s, the importance of the diverse regional material cultures being recognized, provincial museums were meant as tools for unifying the country and for affirming local cultures.

However, as P.M. Taylor (1994a: 2) remarked, the "Unity in Diversity" motto's "obvious contradiction between the unity of a national culture and the diversity of local indigenous traditions reflect[ed] policies that sometimes crush[ed] and sometimes encourage[d] local traditions". Indeed, the state endeavored to carefully sort out the "good cultural traits" from the "bad," and promote the former while stamping out the latter. In its action over the first three five-year Plans (1973/1974 to 1979/1984) to establish provincial state museums, the state thus had a strongly normative character (as the "handbooks" mentioned above attest - and updated regulations on the preservation and utilization of museum collections were released till the late 1990s, e.g., Regulation No. 19 of 1995 (DM 1998, ICOM 2010).

From 1984 onward, however, subsequent to the new Plan Orientation of 1983 (RI 1983), new policies refocused the role and function of museums toward research and "education about culture and identity" (DM 2011). In practice, the focus shifted away from the preservation of culture toward the conservation of objects, or basic cataloguing, thus discouraging local cultural practices, customs, and traditions viewed as possible challenges to the state (see Rath 1997).

Later, the 1991 "Visit Indonesia Year" program motto, "Let's Go Archipelago," again emphasized the country's cultural diversity, albeit for more concrete purposes of promotion of tourism (Sellato 1998), which in the 1980 s had become a crucial currency earner (on the uncomfortable relationship of tourism, nation building, and regional cultures, see Picard 1993, 1997). Indeed, the "Culture" component, for decades under the Ministry of Education and Culture, later was moved to a Ministry of Culture and Tourism, to return to the Ministry of Education in 2009 (DM 2011), and finally to a new Ministry of Education and Culture.

Altogether, considering that citizens construe and articulate anew what the state attempts to impress upon them, the role of museums in the Indonesian 


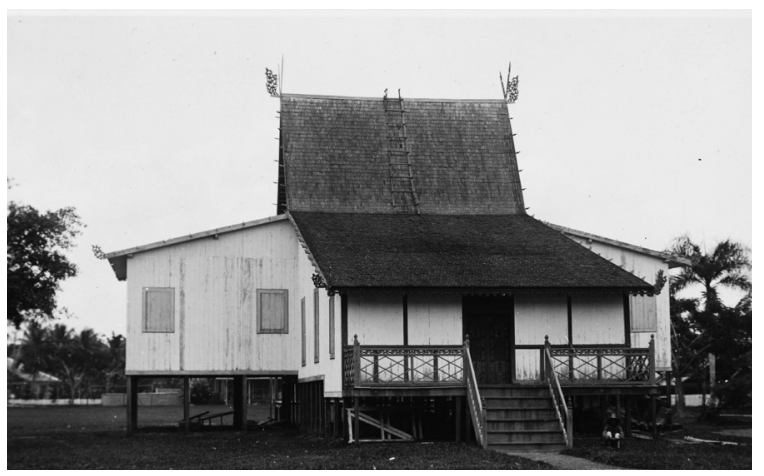

Fig. 2 - The Borneo Museum, in Banjarmasin, was created by the Dutch in 1907 in the typical Banjarese high-ridged house (rumah bubungan tinggi) style, the only noteworthy museum in Dutch Borneo (the photo dates from the 1920s or 1930s). Plundered during the Japanese occupation, it was replaced in 1955 by a Kalimantan Museum, soon destroyed by fire, and later (1967) by a Museum Banjar. (Source: Tropenmuseum TM-60018759).

nation-building enterprise was really a complex one, as Adams (1999) correctly noted.

Although certain recent legal texts on the development of culture and tourism (RI 2005, 2009) do not even mention the word "museum", the Ministry of Education and Culture, following a 2010 presidential decree (RI 2010), has set up a "Strategic Program" (Rencana Strategis) for the 2010-2014 period, which features an energetic Revitalisasi Museum campaign, along with a cute "I Love Museums" national movement (Gerakan Nasional Cinta Museum), in order to upgrade the public image of museums and boost their frequentation (DM 2011). The year 2010 was coined "Visit Museum Year" (Tahun Kunjung Museum), and various booklets were published to support the campaign (e.g., DM 2009a). The Revitalisasi Museum targets the "revitalization" of 36 museums in 2011, and of a total of 80 by the end of the five-year period (Intan Mardiana, pers. com.).

\section{Museums in Kalimantan and decentralization ${ }^{4}$}

In colonial times, collections of material culture from Kalimantan were generally accommodated in the museum of the Batavian Society, and still constitute the bulk of the present-day National Museum's Kalimantan holdings. Large collections, however, whether natural history or cultural artefacts, were shipped to various museums, in the Netherlands and elsewhere in Western countries.

4. Data for this section were extracted from the available literature and various Internet sources, the most important listed under "Internet Sources" at the end of the Reference List. 


\section{Museums in Kalimantan before Decentralization}

It seems that the first and only important museum in Kalimantan during colonial times was the Borneo Museum (fig. 2), founded by the Dutch in Banjarmasin in 1907-though it does not appear in the lists cited above. The Dutch colonial administration is also reported to have, in 1922, established in Sintang, West Kalimantan, in collaboration with the Tropenmuseum of Amsterdam, a Sintang Cultural Center (see IS Sintang; and more below).

The Borneo Museum was later looted during the Japanese occupation. A new one, the Kalimantan Museum, was built in Banjarmasin in 1955, but was soon destroyed by fire. Another museum, Museum Banjar, was created by the governor of South Kalimantan in 1967, and later transferred to several successive locations.

As mentioned above, a second generation of museums, the independent Indonesia's state museums (museum negeri), was in the process of being established in the four Kalimantan provinces during Pelita II (1974/1975 to 1978/1979). By the end of Pelita III, Kalimantan already had two completed and operational state museums: the Museum Lambung Mangkurat in South Kalimantan and the Museum Mulawarman in East Kalimantan (out of ten nation-wide; UNESCO 1985).

In Banjarmasin, the city no longer having a royal palace (see below), the collections of the Museum Banjar were finally transferred to the new Museum Lambung Mangkurat (fig. 3), a modern building reminiscent of a traditional Banjarese house, located at Banjar Baru, some $30 \mathrm{~km}$ away from the city, and inaugurated in 1979. It houses an important collection of Banjarese and Dayak artefacts and a good selection of archaeological objects. In 2008, it received over 45,000 visitors (IS Banjarmasin).

In East Kalimantan, the sultans' old wooden palace in Tenggarong (fig. 4) was replaced, by the turn of the twentieth century, by a new one, also built of wood, and also known as Keraton Kesultanan Kutai Kartanegara ing Martadipura (fig. 5). This latter palace, damaged by fire, was dismantled and replaced in 1932, by a building made of concrete and in Art Déco style (fig. 6) by a Dutch architect named Estourgie, to be handed over in 1936 to Sultan Aji Muhammad Parikesit. After the sultanate was abolished in 1960, the palace was requisitioned during the Confrontation with Malaysia, as East Borneo sultans were then suspected of intending to join the Malaysian Federation (D.P. Tick, pers. com.). It was turned into a museum in 1971 by the East Kalimantan military commander, and finally transferred by the provincial government to the then Ministry of Education and Culture in 1976. It became a state museum, Museum Negeri Mulawarman, in 1979 (IS Kutai). The old mosque and the royal graveyard, both renovated, are located nearby, while a grand new mosque (Masjid Agung) has recently been built, along with a new royal palace (fig. 7), which is in a style reminiscent of the earlytwentieth-century wooden palace and only used for official functions. 


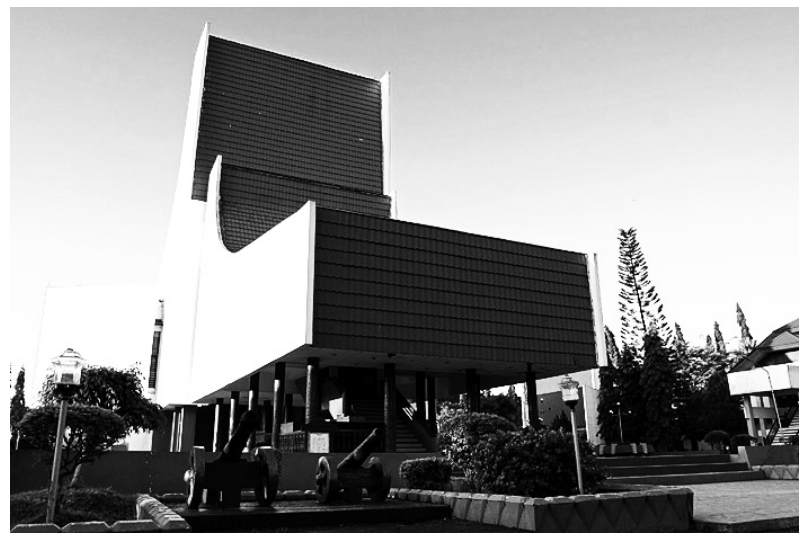

Fig. 3 - The Museum Negeri Lambung Mangkurat's main building at Banjar Baru, some $30 \mathrm{~km}$ to the southeast of Banjarmasin, and just off the road from Banjarmasin to Martapura. Building started in 1974, and the Museum was inaugurated in January 1979. Its architects gave the building a shape reminiscent of the typical Banjarese house. It houses collections of Banjar and Dayak artefacts and archaeological objects from Kalimantan. (Source: purnamatravel.files.wordpress.com; http://www.indonesia-tourism.com/forum/ showthread.php?520-Lambung-Mangkurat-Museum-Banjarbaru-South-Kalimantan\&s=d5167cad49b630 $1662278009 \mathrm{~d} 08376 \mathrm{~d} 5)$.

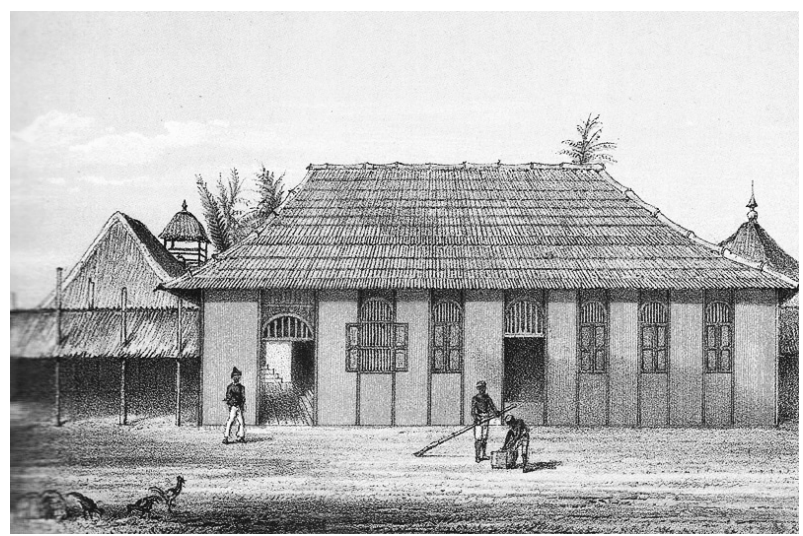

Fig. 4 - The palace compound of the sultan of Kutai at Tenggarong, East Kalimantan (source: Bock 1882: 24, plate 1). Bock was in Kutai in 1879, in the times of Sultan Aji Muhammad Sulaiman Khalifat al-Mukminin, "one of the most intelligent rulers in the Malay archipelago" (1882: 31). He described "a large, square, wooden building, approached through a long covered courtyard, with two openings for doorways, and covered with a corrugated galvanized iron roof." Inside, "this Pandoppo ... had large side galleries," "occupied by fattailed sheep," ... "and another facing the door over a large platform; while part of the floor was occupied by subdivisions, or "rooms." There were "a few lamps, suspended from the lofty roof, which was supported by massive pillars of iron-wood." "I looked in vain, however for chairs or seats of any kind" (1882: 32$)$. 


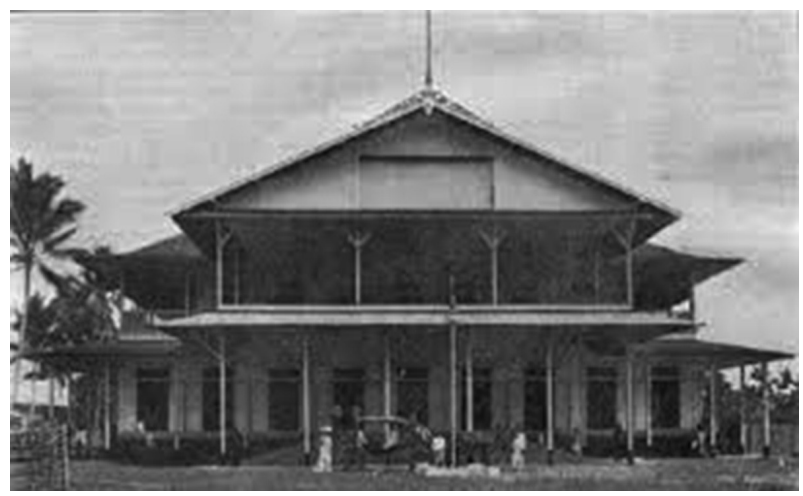

Fig. 5 - The Keraton Kesultanan of Kutai in the times of Sultan Aji Muhammad Alimuddin (r. 1899-1910). Alimuddin, who replaced Sultan Sulaiman, built a new palace, facing the river, also of ironwood, but with two stories. Around 1930, it was badly damaged by fire, and later dismantled, while a new palace made of concrete was built for Sultan Parikesit. (Source: http://kesultanan.kutaikartanegara.com/index. php?menu=Keraton_Kutai).

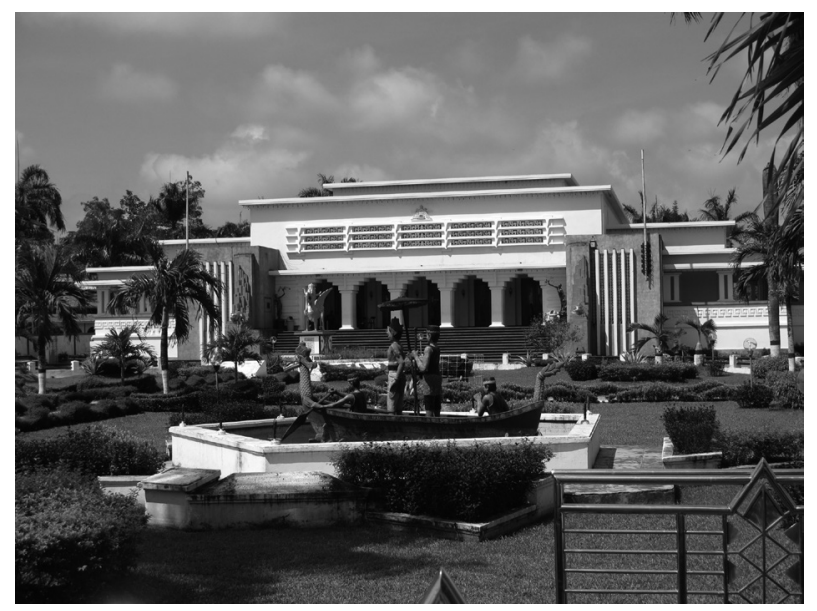

Fig. 6 - The "colonial" Kutai Palace, built in concrete by a Dutch architect for young Sultan Aji Muhammad Parikesit at Tenggarong. Decorated in Art Nouveau style, it faces the Mahakam River across vast front grounds. Started in 1932, it was handed over to the sultan in 1936. After the abolition of the sultanate (1960), the palace was turned into a museum by the military commander of East Kalimantan (1971), then became a state museum, Museum Negeri Mulawarman, in 1979. The obelisk disappeared, but all sorts of fancy new monuments appeared on the front grounds, including a large replica of the winged Lembu Swana, the kingdom's symbol. The museum houses royal paraphernalia, court costumes, archaeological objects, historical documents, a large collection of ceramics, and an ethnographic section of Dayak artefacts (Photo: Bernard Sellato, 2010). 


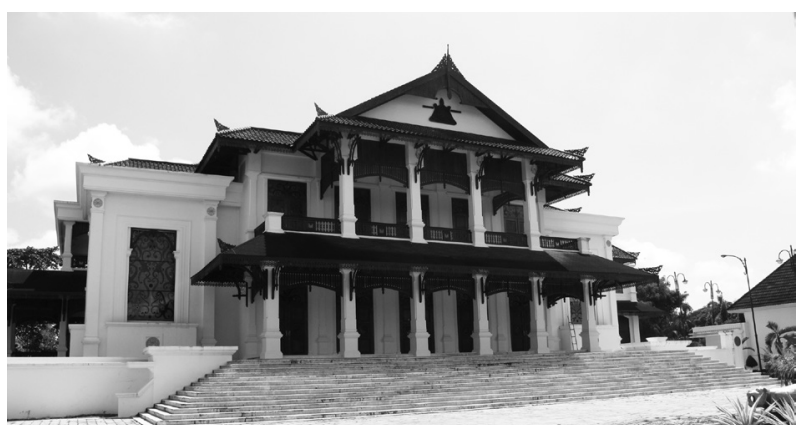

Fig. 7 - The new palace, Kedaton Kutai Kartanegara, of Sultan H.A.M. Salehuddin II, Kutai's new sultan since 2001, was built by the government of Kutai Kartanegara District, in the style of Sultan Alimuddin's palace (Photo: BS, 2010). The aisle walls of the Throne Hall display scores of historical documents and photographs, as well as portraits of earlier sultans. (More information: http://kesultanan.kutaikartanegara. com/index.php?menu=Keraton_Kutai).

In Pontianak, West Kalimantan, the royal family—now headed, since 2004, by Syarif Abubakar Alqadri, the new and ninth sultan - continued to live in the sultan's palace, Keraton Kadriyah (fig. 8), originally built in 1771 by Syarif Abdurrahman Alqadri, a trader of Arab origin, who started the Kadriyah dynasty. The palace, reportedly in rather sad condition, houses the thrones and some regalia, a wooden mimbar, a few cannons, ceramic jars, as well as historical portraits and documents. Nearby stands the old Masjid Jami' Sultan Abdurrahman. The state established a Museum Negeri Propinsi Kalimantan Barat (fig. 9), built in a "mixed traditional and modern style" (see Sellato n.d.; on modern architecture in Kalimantan, see Sellato 1998), which was inaugurated in 1983 and became a state museum in 1988, during Pelita IV. Its exhibits include ethnographic collections, as well as an extensive collection of ceramic jars (see Lombard 1984, IS Pontianak).

In Palangkaraya, the capital city of Central Kalimantan, a new province created in 1957, where no sultanate or palace ever existed, the Museum Balanga (fig. 10) was first established as a regional museum (Museum Daerah) in 1973 by community members concerned about the preservation of their province's cultural heritage (Kreps 1998: 6; 2003: 26). It was designated as a state museum in 1989 and, as such, its 5,000-item collections include generalinterest themes such as "geology, biology, numismatics, and philology" (see SEK 1989-90, IS Palangkaraya). The bulk of its regional-interest collections and its scenography (fig. 11), however, are rooted in the local Ngaju Dayak culture, as described in detail by C. Kreps (2003: 26, 2012).

Government policies regulated the contents (collections and displays) of state museums and, for a part, provided them. They attempted to balance contents between "general interest", focused on the Archipelago and national values and meant to boost national unity and identity, and "regional interest", focused on local cultures. Collections, as in the Museum Lambung 


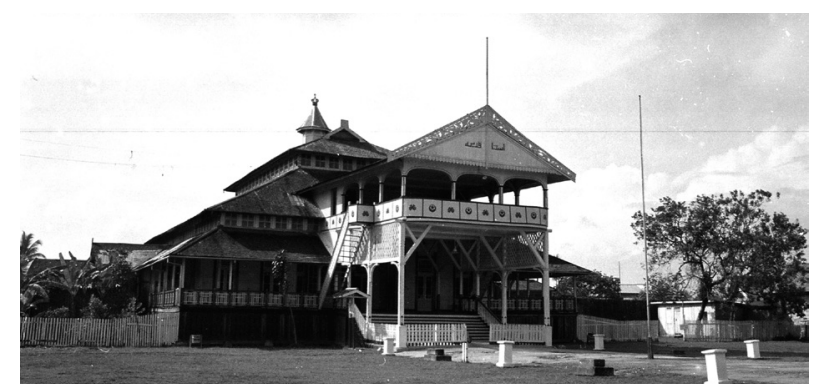

Fig. 8 - The Keraton Kadriyah of Pontianak in 1990. This sturdy, squat palace was originally built by the first sultan, Syarif Abdurrahman Alqadri, in 1771, on the bank of the Kapuas River, next to the Kampung Arab. The broad protruding reception area is a later extension. The royal family was massacred by the Japanese, along with the whole provincial intelligentsia, in the Peristiwa Sungkup (now called Tragedi Mandor). The last sultan, Hamid II, was jailed in 1950, and the sultanate abolished. It was restored in 2004 (Photo: Bernard Sellato, 1990).

Mangkurat, included the following categories: Prehistory, Archaeology, Coins, Ceramics, History, Manuscripts, Modern Arts, Contemporary Crafts, Geography, Astronomy, Geology, Paleontology, Zoology, Botany, Herbarium, and Ethnography. Initially, the local collections often were limited to articles originating from palaces' collections, and therefore mainly reflected MalayJavanese court cultures, but since the 1980s museum programs concentrated on documenting "tribal" (non-Malay) cultures and building basic (Dayak) ethnographic collections.

Such programs, known as proyek-variously called, e.g., "Inventory and Documentation of Regional Culture," "Inventory and Promotion of Cultural Values," or "Museum Development" — initiated and underwritten by the Ministry, gave birth in all provincial state museums to a number of publications (including catalogues) focused on specific local museum

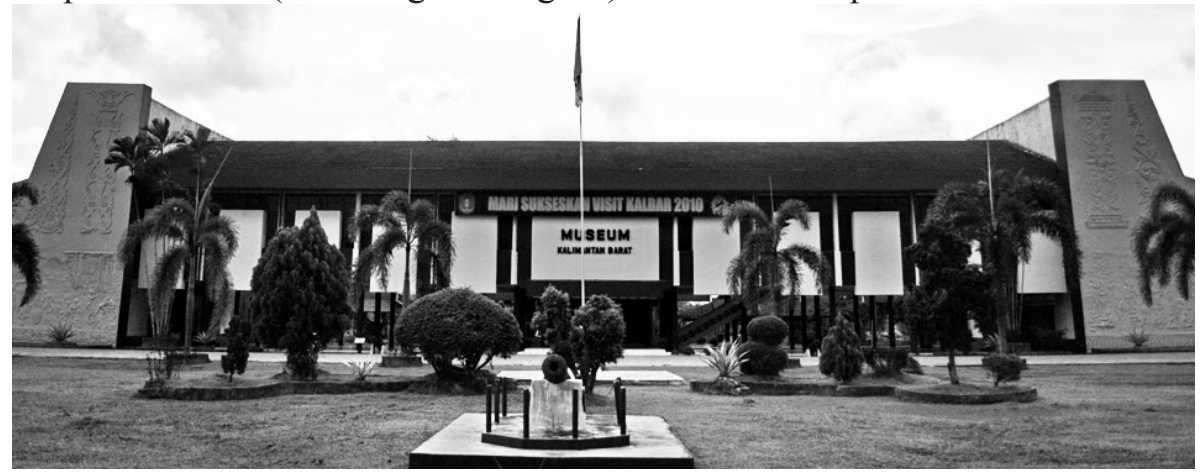

Fig. 9 - The Museum Negeri of West Kalimantan, in Pontianak, in mixed traditional and modern style (partly standing on stilts), was inaugurated in 1983 and is now considered one of the five best museums nationwide. Its exhibits include ethnographic collections (clothing, masks, weapons, brassware, basketry), models of traditional houses, archaeological objects, some 600 ceramic jars, manuscripts and historical documents, as well as collections of rocks and animals. (Source: http:/www.skyscrapercity.com/ showthread.php?t=473704\&page=5). 


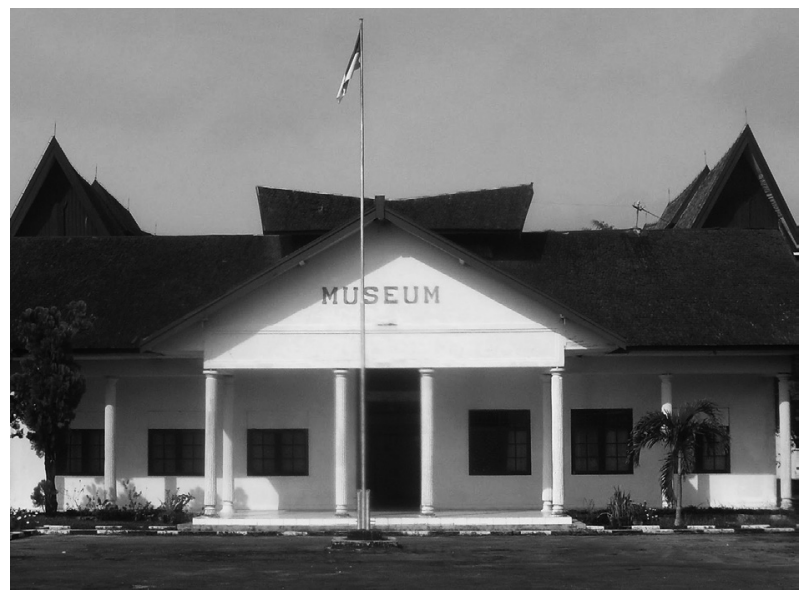

Fig. 10 - The Museum Negeri Balanga, Palangka Raya, Central Kalimantan (c. 1985). In a provincial capital with no historical palace, the Museum Balanga was founded in 1973 as a regional museum (Museum Daerah) by community members concerned about their province's cultural heritage. Built in a "mixed Dayak and modern" style, it was designated as a state museum in 1989 and inaugurated in 1990. (Source: http://mahakam24.blogspot.fr/2014/02/museum-balanga-palangkaraya-kalimantan.html).

collections, or other cultural features, such as traditional architecture (see a review in Sellato in press). Considering that museum staff (civil servants) may or may not comprise participants in the local cultures, such publications are of varying quality. They also are very poorly distributed. Moreover, I never heard that local community members had a say in, or were consulted about what "regional-interest" collections should include.

Regarding "general-interest" collections, the Museum Mulawarman, for example, used to display a collection of traditional costumes of all provinces of Indonesia; miniatures of Java's Borobudur and Prambanan temples; textiles from Sumatra; traditional Indonesian weapons and musical instruments; and a superb collection of Asian and European ceramics, probably originating from the sultan's collection. But several "regional-interest" rooms were dedicated to displays of selected features of the various Dayak cultures, such as wooden sculpture, textile weaving, blowpipes, and basketry.

The Kutai Palace's most precious objects, viewed as part of the "national heritage," were transferred to the National Museum in Jakarta, such as some of the sultans' regalia (e.g., ancient gold objects, such as the twokilogram gold crown, ketopong) or important archaeological pieces (e.g., the famous fifth-century-AD inscribed stone yupa steles). Some of these, however, may have been recently returned to Tenggarong. Other important objects of the palace's paraphernalia were not removed, such as the sultan's throne (singgasana, created by the Dutch maker Van der Lube in 1935), the Lembu Swana statue (a winged mythical animal and the kingdom's symbol, 


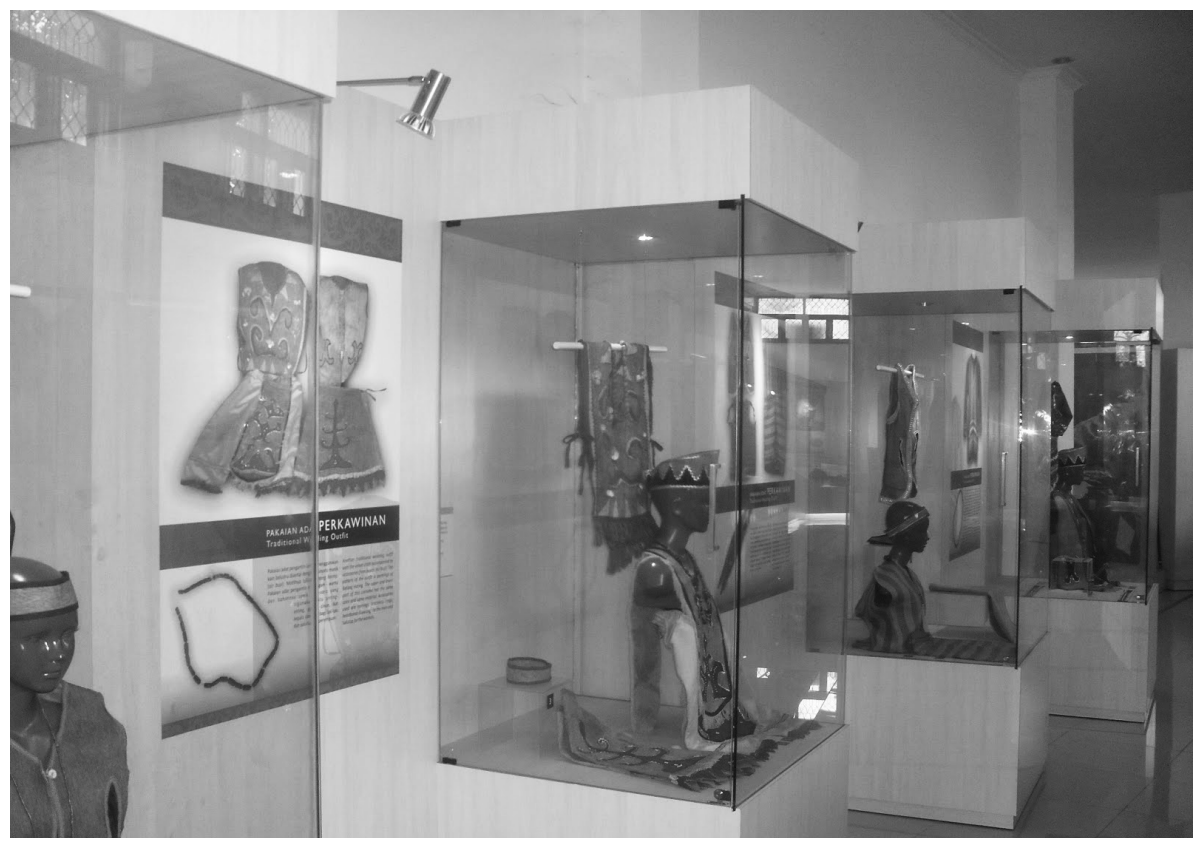

Fig. 11 - The Museum Negeri Balanga, renovated after 2008. It includes a 5,000-item mixed collection, covering both general-interest themes, as provided for by the state, and local-interest, ethnographic themes, as initiated and emphasized by the founders. (Source: http://mahakam24.blogspot.fr/2014/02/museumbalanga-palangkaraya-kalimantan.html).

manufactured in Burma in the 1850s), a gamelan orchestra (presented by the sultan of Yogyakarta in 1855), ritual umbrellas, various historical documents and photographs, and official and court costumes and uniforms.

Interestingly, the transformation of a palace into a museum had not quite erased the spiritual and temporal aura of the sultans' offspring, who still lived next to, and sometimes in the palace. "Although the museum is officially owned by the state and thus intended to function as a public museum, [...] the royal family still use the palace and some of the collection for royal functions and ceremonies. [...T] he sultan's family also has considerable say in museum matters" (Kreps 2003: 57). A similar situation pertained to the palace of the sultans of Ternate in the Moluccas (Taylor 1994b). We shall see below how these royal offspring achieved their return to power.

I shall briefly describe here a few minor palaces-museums, which are not state museums and are managed by district (kabupaten) culture offices. These museums really are local history museums, and keep echoing the former kingdoms, which still have much sway over the local population. The physical buildings themselves, as former seats of power, still contribute to uphold strong local feelings of identity. 


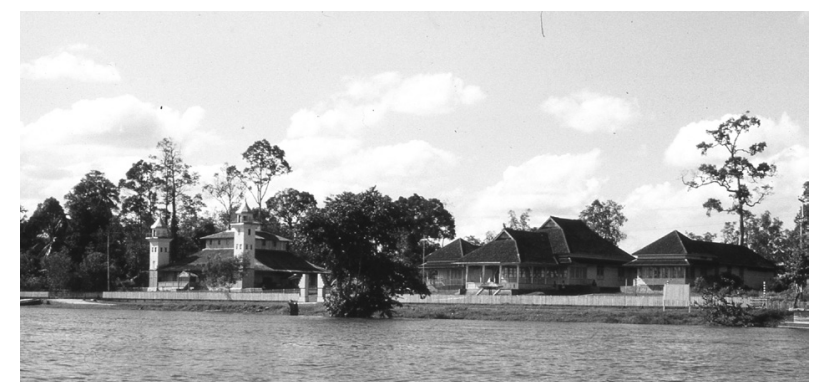

Fig. 12 - Sintang, the only kingdom of some importance in the far interior of Borneo, at the confluence of the Melawi with the Kapuas, in West Kalimantan, became a sultanate in the late seventeenth century, which was abolished in 1959. Replacing earlier palaces, the present Istana al-Mukarramah is located across the Kapuas River from the town of Sintang, at a place called Kampung Raja. It was built in 1937 by the Dutch for the new sultan, Panembahan Muhammad Jamaluddin, and comprised three main buildings, with ironwood pillars sunk in concrete blocks and an asbestos ceiling under an ironwood shingled roof. Nearby is the royal graveyard (Makam Kerabat Istana) and, right downstream, is an old wooden mosque, Masjid Jami' Sultan Nata. The palace's central building was turned by the state into the Museum Dara Juanti (c. 1970), and renovated in 1985. It displayed a Garuda (the kingdom's symbol), weapons, brassware, ceramic jars, painted and photo portraits of past kings and, on its grounds, bronze cannons and a coarse stone lingga called Batu Kundur. (Photo: Bernard Sellato, 1979).

Sintang, an important kingdom of interior West Kalimantan, probably was established before the fifteenth century. Successive palaces, Istana Kerajaan of the late seventeenth century, Istana Panembahan of the 1860s, and Istana al-Mukarramah built in 1937 (see Enthoven 1903, Lontaan 1975) were large wooden houses on stilts, in "Malay" style, generally with a broad veranda serving as a meeting hall. The kingdom was abolished in 1959, and the palace (fig. 12) turned into the Museum Dara Juanti in the early 1970s (Goenadi et al. 1977). Managed by the local government as a cultural heritage monument, the museum displays the former ruler's collections (a gamelan, ceramic jars, cannons, photographs), and some ethnographic objects (see IS Sintang). The palace has recently been renovated (fig. 13).

Pasir, an early (fourteenth century?) coastal polity of East Kalimantan, settled at Paser Belengkong in the sixteenth century under the name Sadurengas. It later became a sultanate, ruled by Bugis or Banjarese overlords. The present palace, actually a not-so-large wooden platform house quite superbly called Kuta Imam Duyu Kina Lenja, with elegant Bugis-style carvings and finials, was built in the mid-nineteenth century and formerly surrounded by ironwood fences (see Handleiding 1884: II, 149-151). In 1908, the sultan handed authority over Pasir to the Dutch, and was later arrested and banished (1918; see Eisenberger 1936: 89-98, cited in Bakker 2008: 154). The Dutch built a new administrative town at Tanah Grogot, leaving Belengkong a backwater place. The palace later became the Museum Sadurengas (fig. 14), with its adjacent old mosque, graveyard, and old cannons, and its collections (fig. 15-16) include ceramic jars, royal outfits, and domestic utensils. It was completely renovated between 2008 and 2010 (fig. 17; and see IS Pasir). 


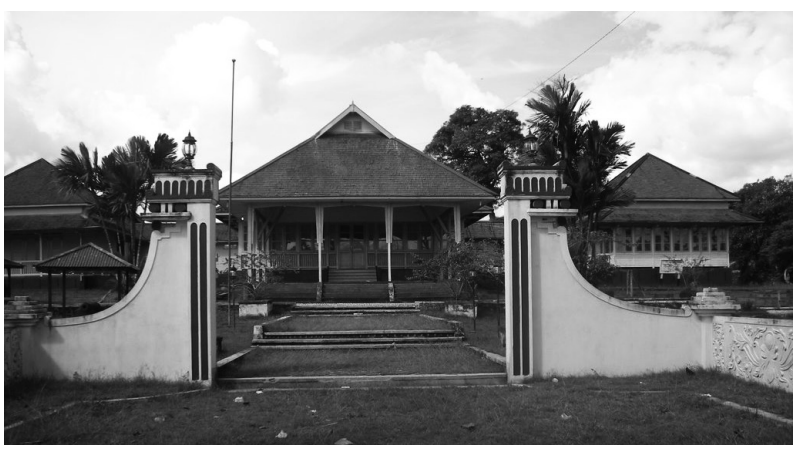

Fig. 13 - The Sintang sultanate was restored (2003) and Muhammad Ikhsani Shafiuddin, in 2005, became its new king, Panembahan Kusuma Negara V, and occupied the recently renovated palace. The museum's collections were moved to the side buildings. Soon after this, the district government of Sintang initiated administrative procedures toward the creation of a new province, Kapuas Raya, to be carved out of West Kalimantan. (Source: http://melayuonline.com/ind/history/dig/431/istana-al-mukarrammah-sintang).

Kotawaringin, a Malay principality, was established on Borneo's south coast before the fourteenth century, then Islamized and taken over, as Kasultanan Kota Ringin, by the Banjarese sultan in the sixteenth century. A palace, Istana al-Nursari, was built in Banjarese style at Kotawaringin Lama, on the Lamandau River, in the late sixteenth century, and probably rebuilt several times. Its old mosque (Mesjid Kyai Gede, now renovated) and royal graveyard can still be seen there. In the early nineteenth century, Sultan Imanuddin moved his capital to Sukabumi Indra Sakti (later known as Pangkalan Bun), on a side stream and closer to the coast, where he built a

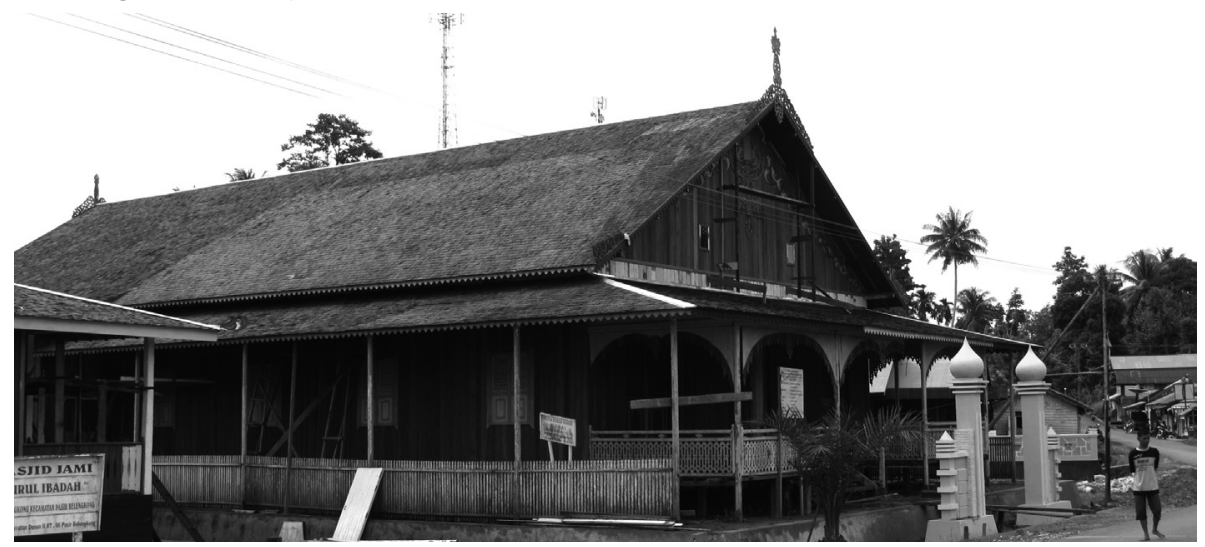

Fig. 14 - The palace of the sultan of Paser Sadurengas, at Paser Belengkong, Paser District, East Kalimantan (in 2010, before the end of renovation work). Built in the mid-nineteenth century by Sultan Aji Tenggara (1844-1873), and named Kuta Imam Duyu Kina Lenja, it is a wooden house on stilts, of relatively modest proportions, with elegant roof finials, surrounded by an old wooden mosque, a royal graveyard, and an enclosure with sacred cannons. Now a museum, Museum Sadurengas, it houses collections of ceramic jars, royal outfits, domestic utensils, and historical documents (Photo: Bernard Sellato, 2010). 

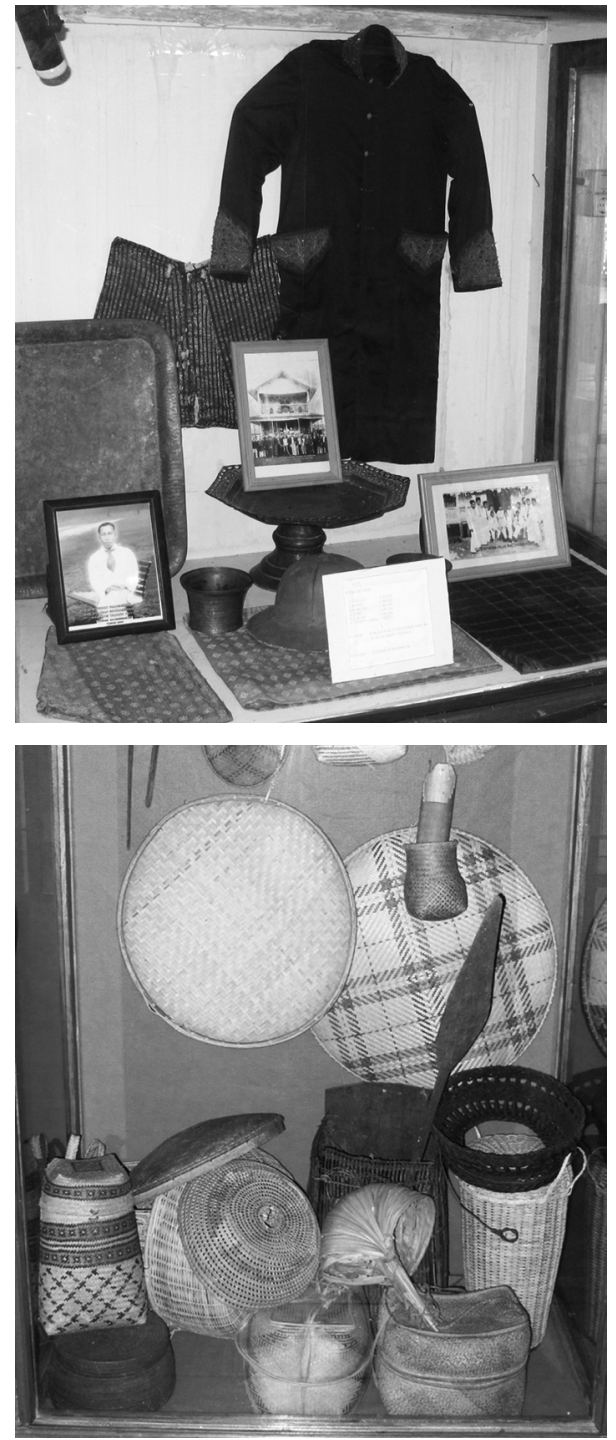

Fig. 15 - Inside the Museum Sadurengas, Paser: part of historical collections: uniform, photographs, brass trays (Photo: Bernard Sellato, 2010).
Fig. 16 - Inside the Museum Sadurengas, Paser: part of ethnographic collections, mostly basketry artefacts (Photo: Bernard Sellato, 2010).

new palace (fig. 18), with the glorious title of Keraton Lawang Agung Bukit Indra Kencana (but usually called Istana Kuning; see Handleiding 1884: II, 111-115, Pijnappel 1968, Gazali 1994, Vita \& Rita 1994: 10-11, Suwedi 1994/1995: 15-20, and IS Kotawaringin). The Istana Kuning was renovated by the state as a museum between 1980 and 1985, damaged by fire in 1986, and rebuilt. Recently renovated again (fig. 19), it houses collections of ancient weapons, ceramics, costumes, and documents. 


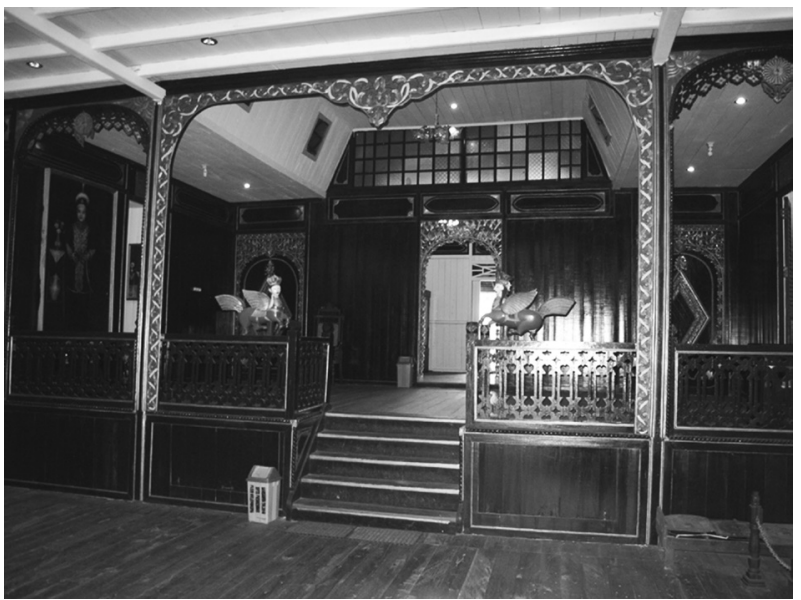

Fig. 17 - Inside the Museum Sadurengas, Paser: the reception hall, with elevated platform and two winged creatures (Photo: Bernard Sellato, 2010).

Apart from such museums, rooted in local minor kingdoms' histories, small museums with a narrow thematic focus have recently emerged, like the Museum Waja Sampai Ka Puting (a.k.a. Wasaka, the motto of the local independence struggle) in Banjarmasin, housed in a converted traditional Banjarese house and inaugurated in 1991, with collections of some 400 objects related to the history of the independence war in South Kalimantan (see IS Banjarmasin).

\section{Decentralization, the Museum Boom, and Depatrimonization}

In the first decade of the new century, in the more open, more liberal context of decentralization, the restoration of a number of sultanates was wrested from and officially recognized by the Indonesian state-e.g., Kutai (2001), Sintang (2003), Pontianak (2004) — while Banjarmasin long remained the object of a dynastic dispute. Subsequently, a law was passed (c. 2008) to the effect that the traditional kingdoms' cultural heritage should be protected (D.P. Tick, pers. com.). Subsequent to such restorations, descendants of sultans everywhere in the country - and even in the tiniest former local polities - were enthroned, and some demanded the restitution of their forebears' palaces and property, and sometimes "territories" (on the Pasir case, see Bakker 2008), and these new kings now endeavor to also restore for themselves a focal position in the current increasingly lively and localized cultural and, quite importantly, political setting.

The post-New Order political and administrative decentralization laws also devolved much "cultural" autonomy to lower administrative levels (daerah: province and district; see RI 2000, 2004, 2007), whereby regional 


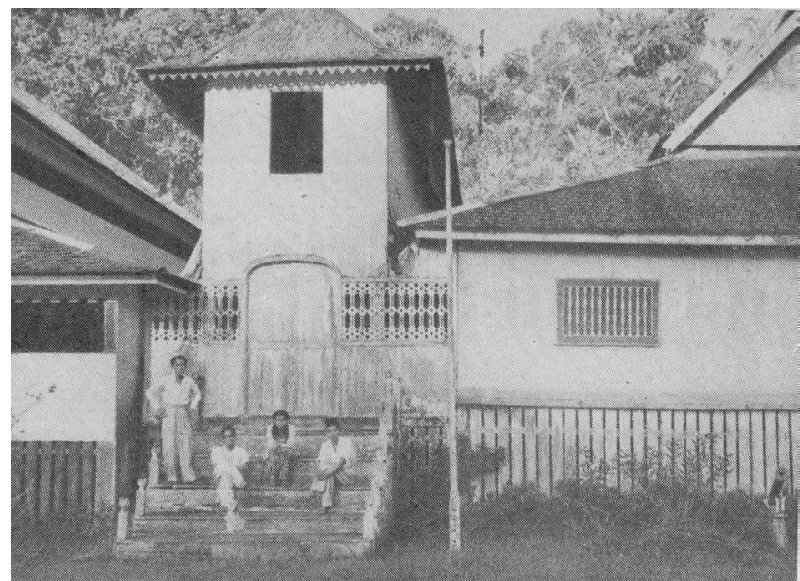

Fig. 18 - The Istana Kuning, at Pangkalan Bun, Central Kalimantan, before 1950. An ancient kingdom mentioned in the Nägara-kertāgama, Kota Waringin became a sultanate in the sixteenth century. The sultanate was abolished in 1959 but, in 2010, Pangeran Ratu Alidin Sukma Alamsyah was installed as its fifteenth sultan. This palace, also called Keraton Indra Kencana, was built in the first decade of the nineteenth century by the ninth sultan, Pangeran Ratu Imanuddin (r. 1805-1841), after he moved his capital from Kota Waringin Lama, on the Lamandau River, to Pangkalan Bun, on the Arut River. Made of ironwood, it is said to combine stylistic influences from Java, Banjar, Malay, and Dayak. The Istana Kuning was renovated by the state as a museum between 1980 and 1985, damaged by fire in 1986, and rebuilt. Recently renovated again, it houses a collection of ancient weapons, oars, jewelry, costumes, ceramics, and portraits, as well as a seventeenth-century Dutch cannon. (Source: RIK 1953: 434).

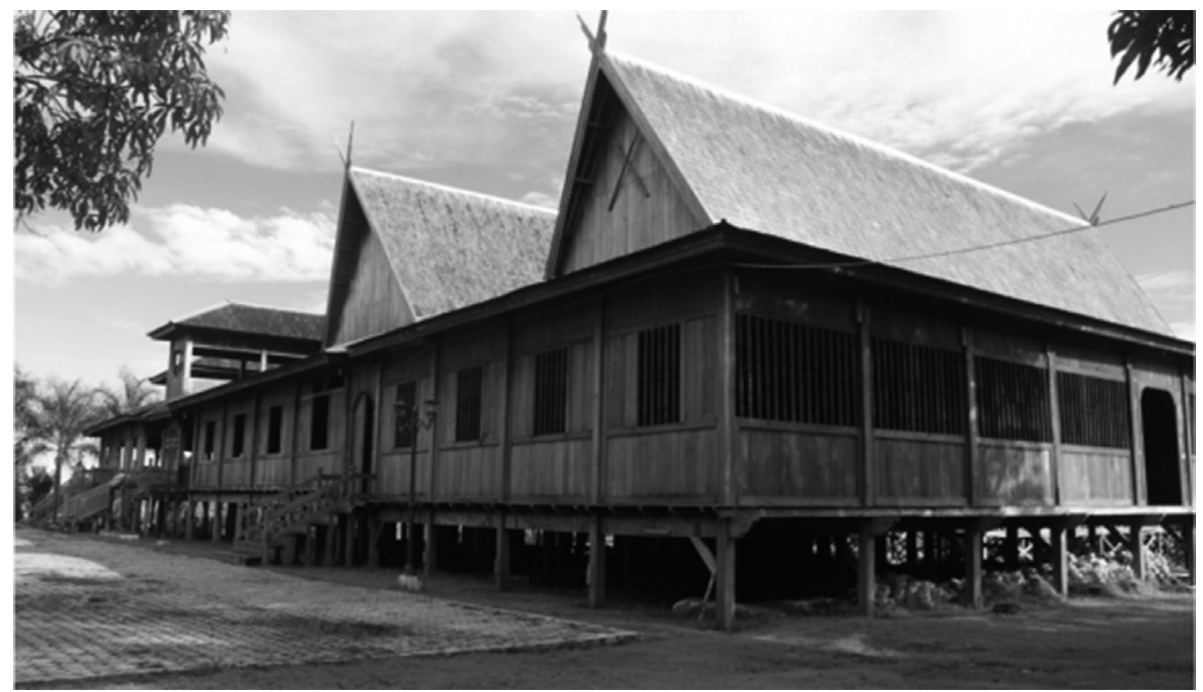

Fig. 19 - The Istana Kuning, after renovation. The three main buildings, and the entrance and tower in the background. (Source: http://aditya-pbun.blogspot.fr/2013/07/kesultanan-islam-pertama-di-kalimantan.html). 
governments now have authority over policies of cultural development, including the establishment of "regional museums" (museum daerah).

At provincial level, in the framework of the post-2000 "new paradigm," state museums are now fully run by the provincial government, practically by a "technical executive unit" (UPT, Unit Pelaksana Teknis) of the Section of Museums and Antiquities (Bidang Permuseuman dan Peninggalan Sejarah) of the provincial Office (Dinas) of the Ministry of Education and Culture (DM 2011). Due to the recent centrifugal trends, however, administrative authority over state museums, as well as over policies, may be devolved to districts, and may vary with provinces, and even with districts. In any event, with increased economic affluence, provincial or district governments (PEMDA, Pemerintah Daerah), now in charge of keeping and displaying cultural collections, seem to spend much more liberally on "their" museums than did the state before decentralization.

In the first decade of this century, with an increasingly inward-focused cultural and political life at province (formerly propinsi, now provinsi) and district (kabupaten) levels, a strengthened local identity, and greater financial means, both museums and sultans' palaces have become important stakes. A third generation of museums, initiated and subsidized by local governments, newly enthroned sultans (or pretenders), as well as, most probably, corporate donors, is blooming, on a much larger scale than their predecessors.

In Kutai, a huge new museum has just been built, next to, and meant to replace, the old Mulawarman palace cum state museum. Next to the old mosque, Masjid Jami' Aji Amir Hasanuddin, said to have been built upon the coming of Islam to Kutai in the seventeenth century, the recently collapsed minaret was replaced by a modern-style tower. An ostentatious new palace, called Kedaton Kutai Kartanegara (fig. 7), was also built for the new sultan, Aji Muhammad Salehuddin II, who, on 24 November 2010, invited sultans from all over Indonesia to celebrate in grand style the 1,660th anniversary of the kingdom of Kutai (purportedly founded by Maharaja Sri Kundungga in $350 \mathrm{AD}$ ), thus establishing nationwide seniority among fellow sultans (Kaltim Post 2010).

In South Kalimantan, due to frequent moves of the seat of power, a war lost to the Dutch (1859-1865), and the subsequent official extinction of the sultanate (1905; see Van Rees 1867, Idwar 1958, 1975, 1982/1983), the old palace of the 1850s (fig. 20-21) was ruined and no new palace was ever built. As of 2012, no new sultan had yet been enthroned, but for Prince Khairul Saleh, then a leading wannabe sultan and a district head in Banjarmasin (RAI 2012), the city bought land and underwrote the construction of a new palace. Eventually, Khairul Saleh became sultan of Banjarmasin, district head of Banjarmasin City (and head of the Council of Borneo Sultans; D.P. Tick, pers. com.).

Interestingly, Banjarmasin architects had to turn to mid-nineteenth-century Dutch engravings for inspiration (e.g., Schwaner 1853-54), and the new sultan 


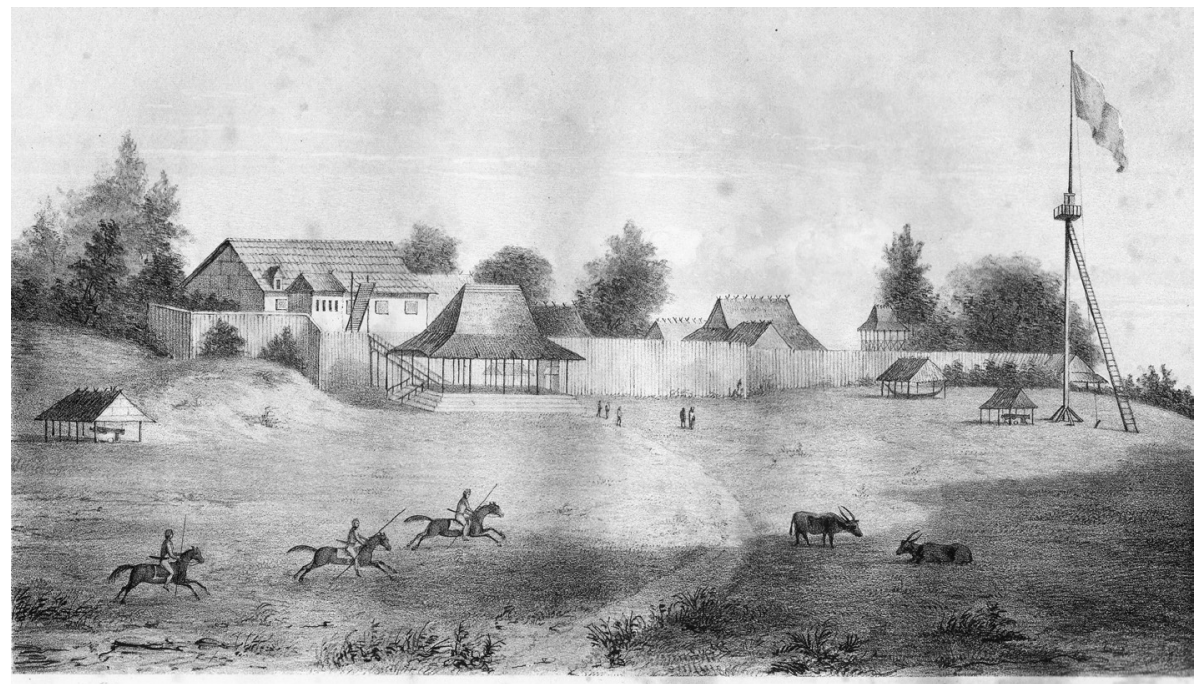

DE KRATON VAN DEN SULTAN VAN BANDJEAMASIH

Fig. 20 - The Keraton (or Dalem) of Martapura, the palace compound of the sultan of Banjarmasin at Martapura, c. 1845 (source: Schwaner 1853-54). C.AL.M. Schwaner travelled in the area between 1843 and 1847. This plate is probably one of the 27 tinted lithographs made by C.W. Mieling (see also Buddingh 1867).

of Landak, West Kalimantan, used Dutch archive documents to design his new palace in the old 'Malay' style (D.P. Tick, pers. com.) — in Brunei Darussalam, as De Vienne (2012) reports, architects resorted to old British engravings (e.g., Marryat 1848) to rebuild the sultan's lapau ceremonial hall, which had been destroyed during World War II.

The restoration of sultans involves important stakes for the political factions competing for power at provincial or district level. In South Kalimantan, long affected by dynastic disputes, one faction successfully lobbied for Khairul Saleh's choice as sultan, while another was supporting another claimant and had a new palace built for him in another town upriver. In Kutai, the faction that had supported Sultan Aji Muhammad Salehuddin II apparently became dissatisfied with his later, more independent stance and prompted, as a political alternative, the comeback of another dynastic line, that of Kutai Martadipura, a kingdom conquered and abolished by Kutai Kartanegara in the eighteenth century (D.P. Tick, pers. com.).

In this increasingly prestigious setting, for both sultans and local governments, customary "tribute remittance" festivals like the Erau in Kutai or Birau in Bulungan, which traditionally were held annually for hinterland tribes to renew their allegiance to sultans, have now been turned into huge, high-profile touristic events, with dance and music performances, handicraft 


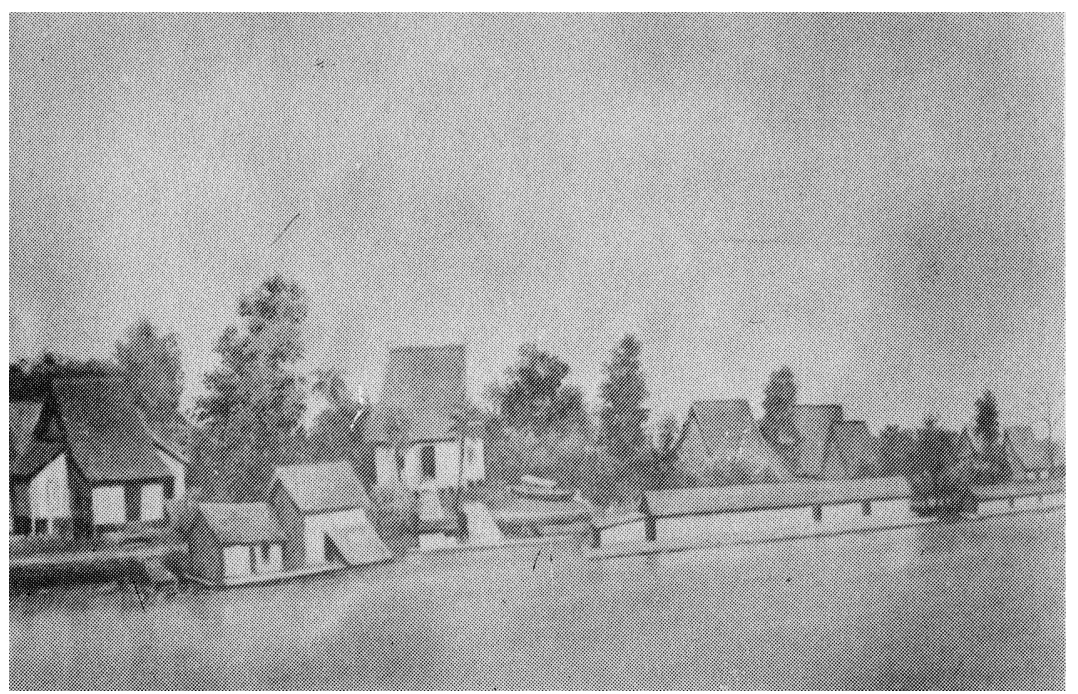

Fig. 21 - A waterfront view of the last palace of the Banjar sultans, at Sungai Mesa, c. 1857. This was Sultan Tamjid's (Tamjidillah's) palace, from where he tried to rule, from 1857 to 1859 , before he was exiled to Bogor. It was standing across the Martapura river from the Dutch resident's office (source: Idwar Saleh 1982/1983: 39; Museum Negeri Lambung Mangkurat, Inv. No. S. 3559). This scene was possibly reproduced by the Museum from Werdmüller von Elgg's Schetsen uit Bandjarmasin (1863).

sales, blowpipe contests, and longboat regattas, to boost regional status and local governments' revenue. Provincial and district tourism agencies (Dinas Pariwisata) endeavor to promote such events - as well as their museums, among other "touristic items" (obyek pariwisata) - to national and international customers, now through websites.

In smaller towns, mostly districtcapitals, the palaces of minor sultanates have recently been renovated - or, sometimes, totally rebuilt — and house small nonstate museums. In coastal East Kalimantan, a Museum Kesultanan Bulungan (fig. 22-23) has been established, and both the twin and rival Sambaliung and Gunung Tabur sultanates' palaces in Berau were renovated, the latter housing the Museum Batiwakkal. In the southeast, Bugis principalities of the Tanah Bumbu area are now in the process of reinstalling themselves (D.P. Tick, pers. com.). In West Kalimantan, the Matan Palace (fig. 24-25), the Mempawah Palace (fig. 26-27), and the Sanggau Palace (fig. 28) were renovated or rebuilt, each including a small museum. Palaces in Sekadau, Sambas, Mempawah, and Tayan, all in West Kalimantan, also were renovated, while the six minor principalities in Kapuas Hulu District very recently showed some signs of revival, initiated by the local government (D.P. Tick, pers. com.).

Such local museums, which may be visited, display regalia, old weapons, and historical documents and photographs. They also attest to the converging interests of impoverished royal families in quest of resources and affluent 


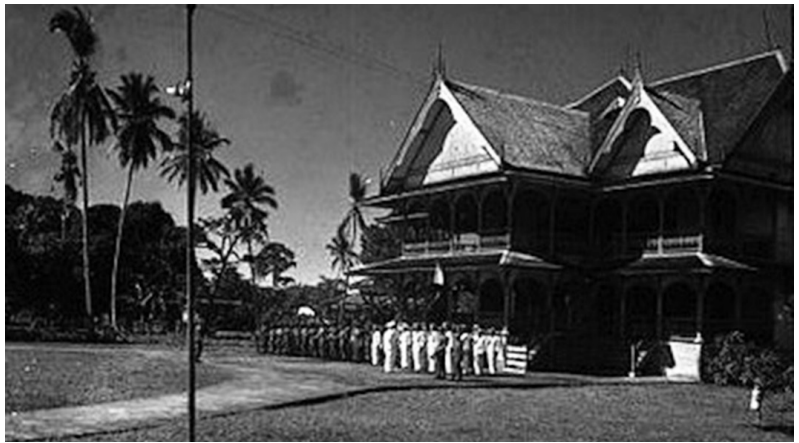

Fig. 22 - The palace of the sultan of Bulungan, at Tanjung Palas, across the Bulungan (or Kayan) River from Tanjung Selor, the capital of Bulungan District, East Kalimantan, c. 1950. After the death of Sultan Jalaluddin (1958), the sultanate suffered the 18 July 1964 "Tragedi Bultiken," in which an Indonesian army unit massacred and abducted royal family members, and looted and burnt the palace. (Source: http://www.bulungan.go.id ; in http://muhammadzarkasy-bulungan.blogspot.fr/).

district governments in quest of spiritual aura (see below) and legitimacy (and, possibly, tourism revenue). Interestingly, renovated palaces of ancient Indianized kingdoms often were painted a rich golden yellow, while those of more recent (or historically Bugis- or Makassar-controlled) sultanates were painted green.

In Sintang, Kesuma Negara V (installed in 2005 as panembahan and in 2006 as sultan; RAI 2012) and his family now occupy the old Istana Al Mukarramah's main building, and only side buildings housing the Museum Dara Juanti remain open to visitors (fig. 13). A renovation project by the

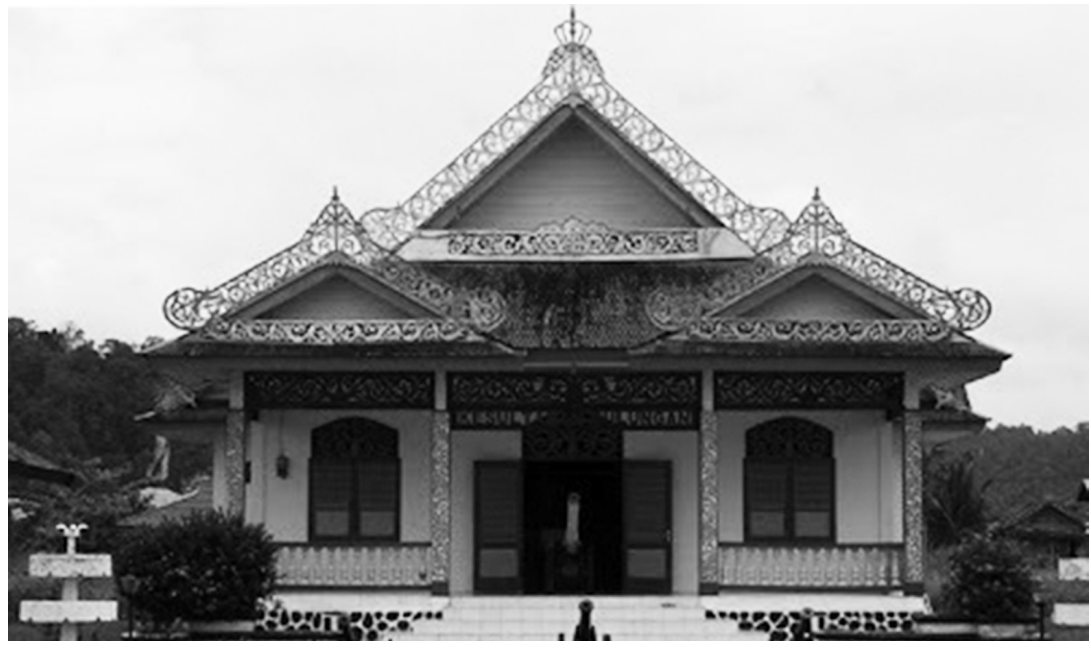

Fig. 23 - The new Museum Kesultanan Bulungan was built in c. 2000 at Tanjung Palas, in a style reminiscent of the old palace, "but in [much] smaller size." Old cannons are set on the front grounds, facing the Kayan River. Collections include what was salvaged from the looting and destruction: some furniture, Malay krisses, ceramic jars, and photographs. A new sultan, Maulana al-Mamun Ibni Muhammad Maulana Jalaluddin, was inaugurated in 2013. (Source: http://springocean83.wordpress.com/author/springocean83/page/2/). 


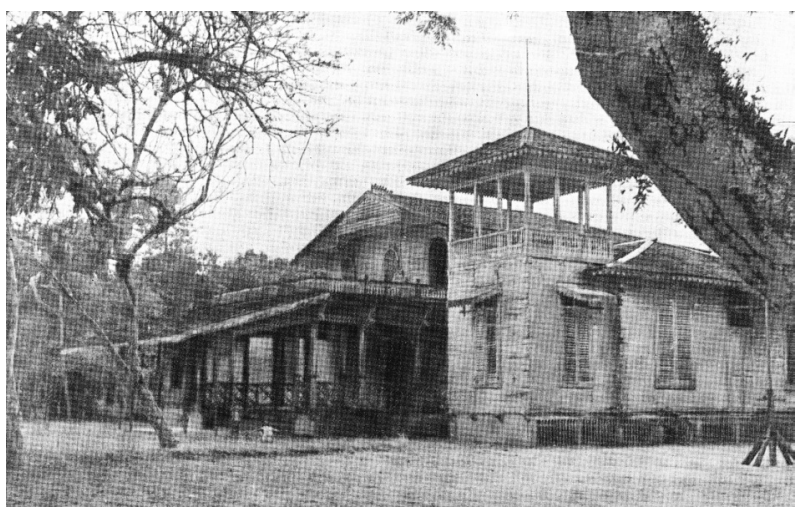

Fig. 24 - The Matan Palace, called Istana Matan Tanjung Pura or Istana Mulya Kerta, at Ketapang, in the southwest of Kalimantan, in the early 1970s. It was built in the second half of the nineteenth century by Muhammad Sabran, fourteenth panembahan of Matan, totally rebuilt in the early twentieth century, in "a more European style," by the Western-educated Panembahan Gusti Muhammad Saunan, and recently renovated. While the tower was meant as a watch post, a cannon called Meriam Padam Pelita is set on the grounds. (source: Lontaan 1975: 92; http://syawalcueexs.blogspot.fr/2013/08/kerajaankeraton-matantanjung-pura.html).

Sintang district government, in the early 2000s, was abandoned, probably due to the sultan's averseness. Instead, a new project, the Sintang Cultural Center (Pusat Kebudayaan Sintang; fig. 29), was jointly initiated in 2004 by the Sintang district government and the Royal Tropical Institute (KIT) of Amsterdam, as part of a "New Museum" program (C. Kreps, pers. com.; see also Fienieg 2007). Its museum cum library, Museum Kapuas Raya, was inaugurated in 2008. This center is conceived of as an educational and recreational cultural focal point for local residents. Ecumenically representing the region's three peoples (Dayak, Malay, and Chinese), its collections include

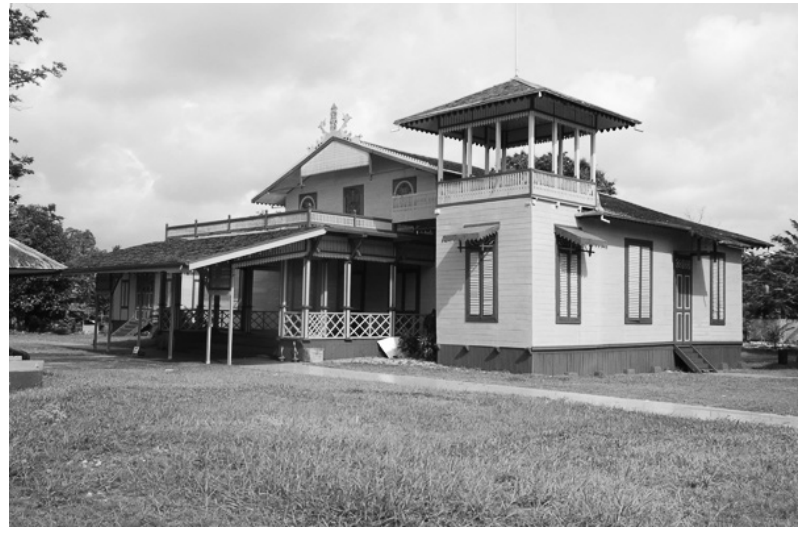

Fig. 25 - The Matan Palace in 2010, after renovation. Collections include thrones, furniture, batik and other textiles, and portraits and photos. (Source: http://liveinbalikpapan.blogspot.fr/2012/09/kerajaantanjungpura.html). 


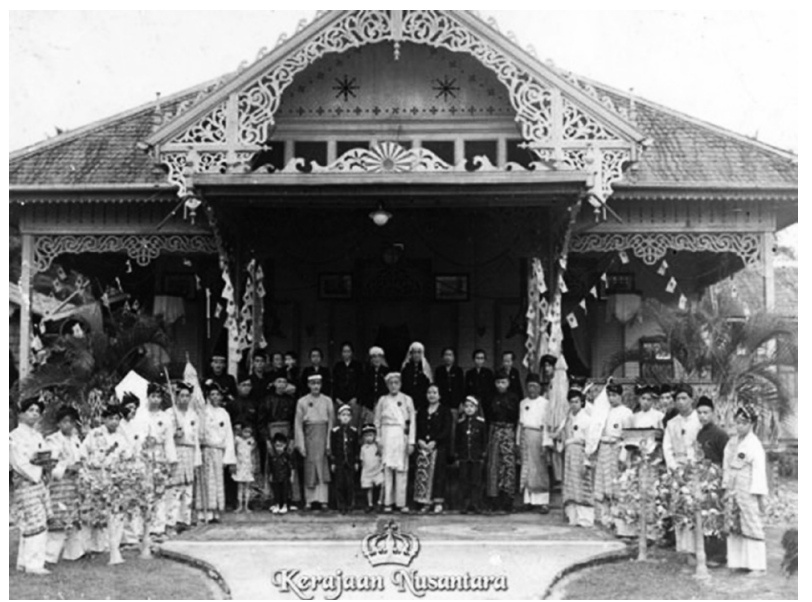

Fig. 26 - The Mempawah Palace, called Istana Amantubillah Mempawah, on Borneo's northwest coast (c. 1930). It was built c. 1770 by Panembahan Adiwijaya Kesuma, a successor to the Bugis founder of the Amantubillah sultanate (c. 1750). The last sultan died in 1944 at the hands of the Japanese, but a new prince, Mardan Adijaya, took the throne in 2002. The palace was damaged by fire in 1880, renovated in 1922, and again very recently. (Source: KOI in http://dedy-afriyanto.blogspot.fr/).

ceramics, weapons, daily utensils, musical instruments, and old photographs (fig. 30; and see IS Sintang).

Other rich districts, in their turn, are now funding the creation of local museums, sometimes in relation to particular regional economic or cultural features, as with the Museum Kayu Tuah Himba in Tenggarong (see IS Kutai), dedicated to forests and forestry, and a museum project in Sangatta, East Kalimantan, focusing on the history of the region's coal exploitation and on the more recent palm oil industry (A. Guerreiro, pers. com.). One may imagine that local business corporations contributed heavily to the funding. More often than not, foundations (yayasan) are established to raise funds

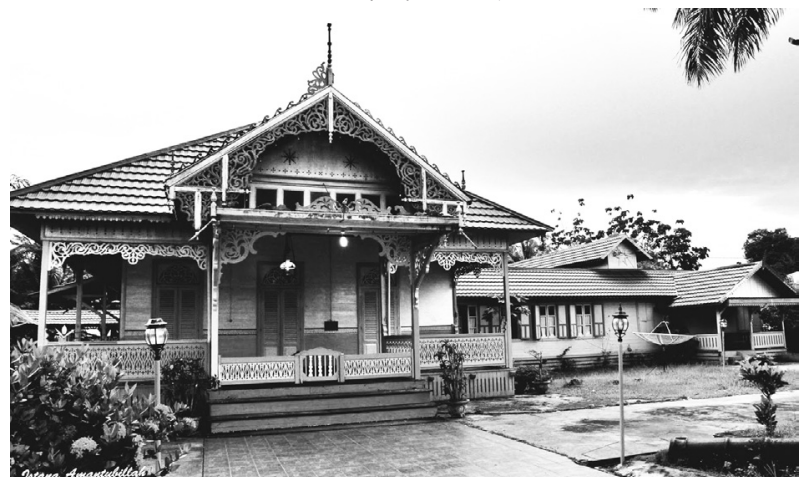

Fig. 27 - The Mempawah Palace c. 2010, after renovation. The main building serves as a museum, exhibiting regalia, a large set of weapons, documents, portraits, and photos. Located nearby are an old mosque and the royal graveyard. (Source:_http://www.wisatakalbar.bl.ee/index.php/history-tourism). 


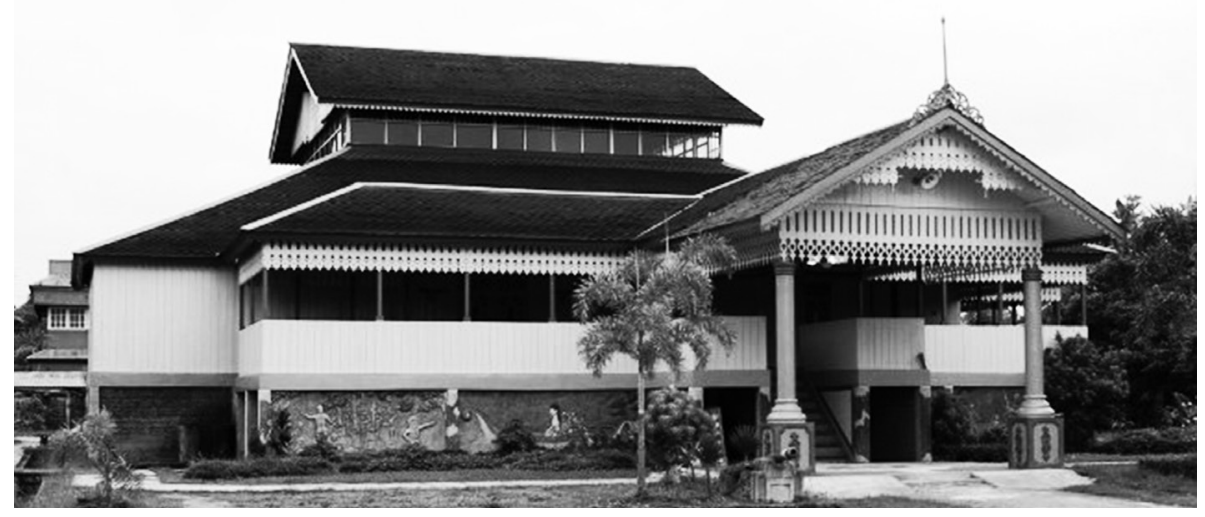

Fig. 28 - The Istana Kuta of Sanggau, West Kalimantan, c. 2010 (after renovation). An old kingdom, claimed to date back to the early fourteenth century, Sanggau is located some distance up the Kapuas River from Pontianak. This is Istana Kuta, the older of two palaces, as Sanggau, since c. 1740, has had two royal branches, Istana Kuta and Istana Beringin, alternating in the sultan's position. The Istana Kuta was originally built by Sultan Zainuddin (r. 1722-1741). The sultanate was abolished in 1960, and the palace was found in a sorry state of decay in the 1980s. Now called Keraton Surya Negara, it was renovated in 2009, as Pangeran Ratu H. Gusti Arman Surya Negara was installed as the new sultan of Sanggau. The compound comprises several buildings (Rumah Laut, Rh. Balai, Rh. Penghulu, Rh. Wredhana, etc.). In its Rumah Darat are kept historical collections, including royal costumes, umbrella, krisses, royal seals, musical instruments, manuscripts and photographs. Although the palace may be visited, it is not a public museum. (Source: catur prasetyo sp, http://www.panoramio.com/photo/28009151).

and run these projects. Another project, also in Sangatta, focuses on recent archaeological discoveries in nearby caves (Chazine in press). In Amuntai, South Kalimantan, a Museum Candi Agung was recently established around a fifteenth-century Hindu temple, most probably involving expertise from the National Archaeological Center and funding from Jakarta.

The central Directorate in Jakarta, anticipating a continuing explosion in the numbers of local museums and wishing to mediate as a guide and referent in their establishment, has recently issued a booklet of advice to interested parties: "How to Start a Museum" (DM 2009b).

However, beyond an obvious quest for prestige, as expressed in the new museums' often grand physical buildings, regional governments' true longterm commitment - with follow-up funding for staff development, collection acquisition, and proper maintenance-may be questioned, as well as their continuing pursuit of the central state's earlier explicit, though ambiguous, policy of "preserving and developing regional cultures."

\section{New trends and the palaces' future}

Sultans' palaces in Indonesian Borneo have experienced a long period of progressive patrimonization in the course of a half century of nation-building policies (1950/2000), and are now being reverted to the descendants of their 


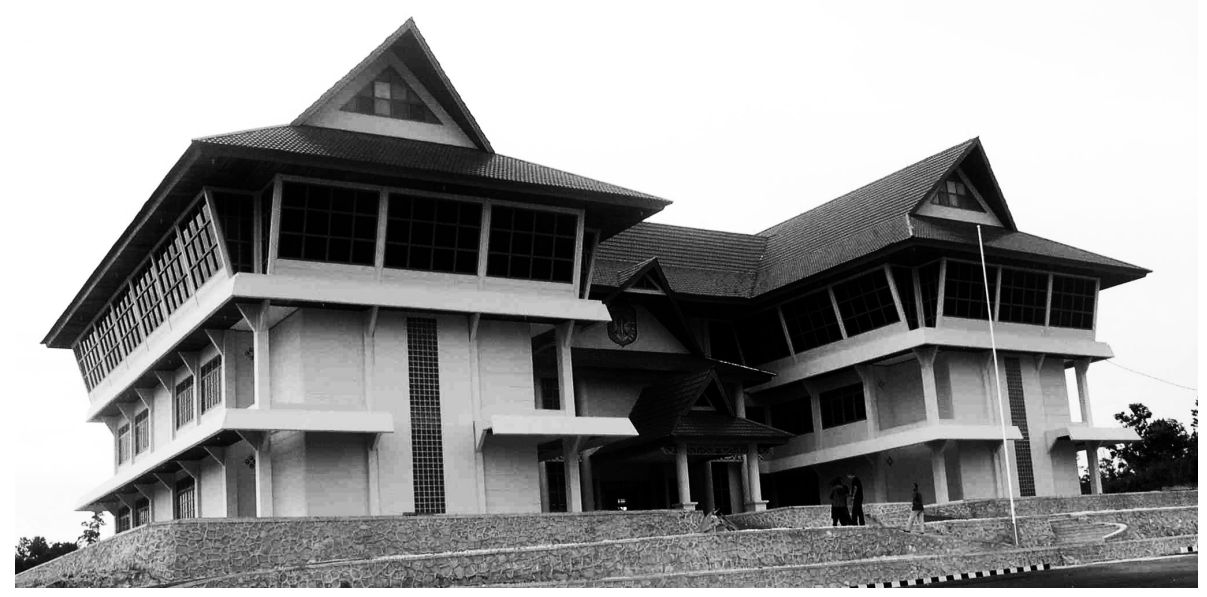

Fig. 29 - The new Sintang Cultural Center (SCC). The Dutch administration, in collaboration with the Tropenmuseum of Amsterdam, reportedly established, as early as in 1922 a Sintang Cultural Center. In September 2004, a new project, the Sintang Cultural Center (Pusat Kebudayaan Sintang), was jointly initiated by the Sintang district government and the (Catholic) Kobus Foundation, and implemented by the Royal Tropical Institute (KIT) of Amsterdam. The SCC is an educational and recreational structure, meant as "a symbol of peace, harmony and tolerance in an area where ethnic violence was once strongly felt," complete with archives, library, and exhibition space. (Source: http://www.culturalheritageconnections.org/ wiki/Pusat_Kebudayaan_Sintang).

former owners in a rather abrupt process of depatrimonization over about a decade, subsequent to extensive decentralization and regional autonomy.

\section{Palaces and Power}

Sultans' palaces had been turned into museums, and their contents - their owners' somewhat private familial and historical heritage and collectionsappropriated by the state, removed, studied, catalogued, and exhibited to the public. During that period, palace buildings were properly maintained (or not) by relevant state agencies, renovated or left to collapse, and their collections were (or were not) properly and securely cared for. Meanwhile, sultans' descendants, usually large extended families, having also lost a hefty portion of their traditional revenue, were left politically powerless and economically impoverished - but sometimes only relatively so.

With the reversion of palaces to these sultans' offspring, we have come to realize that sultans' power has never been totally lost, and that the spiritual aura of the palace, albeit as a "democratic museum," has never really waned in the minds of the local population. Moreover, the existence of an ancient "royal graveyard" (makam raja), as well as of special sites or objects (e.g., old cannons) viewed as sacred (pusaka or keramat), located in the vicinity of a palace, adds to its spiritual aura. With palace restitution and sultan enthronement, the re-creation of the sultan-palace symbolic pair is tantamount 


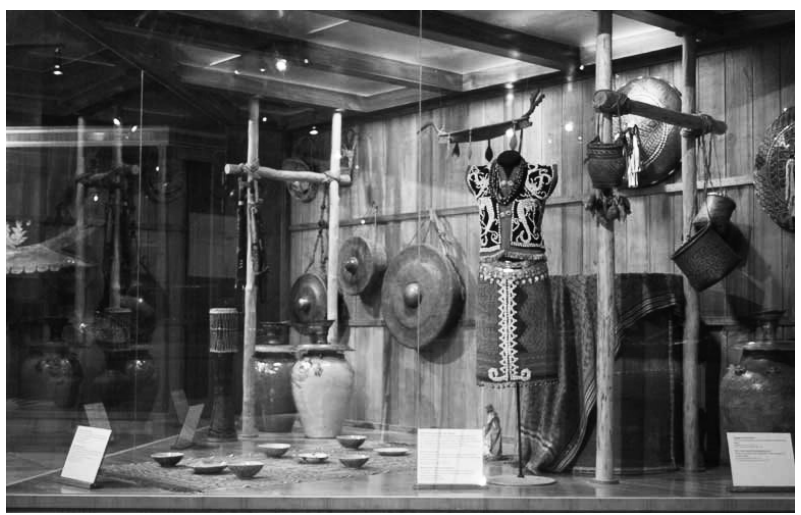

Fig. 30 - Inside the Sintang Cultural Center, the Museum Kapuas Raya Inaugurated in 2008, it is meant to represent the three local ethnic cultures (Melayu, Dayak, and Chinese) and to strengthen and revitalize them. These groups were involved in the making of the museum, and staff was trained in Sintang and the Netherlands. In its three fine main exhibition rooms are collections of ceramics, costumes, ikat textiles, weapons, musical instruments, domestic utensils, ritual objects, documents, and photographs. (Source: http://kerajaan-indonesia.blogspot.fr/2008/12/opening-museum-of-kapuas-raya-of.html).

to resurrecting the sultanate. As Van Klinken, in his excellent "Return of the Sultans" article (2007), writes: "The sultans play a symbolic role in an emerging local dynamic in which the stakes include bureaucratic power and control over land." We now see sultans' descendants rather easily gaining access to modern positions of power, for instance, as district heads, and in any case wielding much influence, directly or offstage, over regional politics.

Throughout the Indonesian republic's history, modern leaders, including presidents, consistently strived to attain the status of, and be regarded as, traditional leaders-i.e., "kings" or sultans - complete with the required spiritual inspiration (wahyu) and collections of pusaka, whether ceramic jars or old portraits. With the reversion of their palaces, the sultans' descendants ipso facto recovered that power in the eyes of "their" people, who now often are their constituency. Many new sultans had books published, illustrated with historical documents and photos, to strengthen their legitimacy and their kingdom's stature, prestige, and antiquity, and exalt its spiritual aura (e.g., Bilfaqih 2006).

Today, therefore, with depatrimonization, palaces are starting a new lifeor, rather, somehow resuming their pre-colonial life - as the focal points of power and of local and regional political and cultural life and identity. It does not matter, actually, whether it is the old palace or a new one, provided that all the necessary rituals are carried out to make it spiritually efficient, and that all the important, potent historical pusaka are present.

\section{Palaces as both Traditional and "New Museums"}

Over the last few decades, scholars and the civil society alike have stressed the need to involve the local people in the elaboration of the museums 
meant to represent them (see Tan 2010). The "New Museology" movement, intended to help "decolonize" museums, promotes community-based museum development: Museums should grow out of the communities in which they exist, and their purposes and meanings should be determined by these communities, in the process of defining themselves (see Kreps 1998). This is, indeed, how community members initially established the Museum Balanga of Central Kalimantan (Kreps 1998, 2003; see another case study in Andini 2011). Features of this new model of museums seem to have, in Indonesia, been endorsed readily by the Directorate of Museums, which stresses that a museum must be a forum and a "contact zone" (DM 2011).

Students and promoters of "non-Western models of museums" envision certain traditional practices, such as collecting and storing valuable objects, which tell us about what local people view as important, as alternative curatorial practices. Such curatorial-type behavior, focused on traditional forms of heritage management, is a cross-cultural phenomenon of great historical depth, as Kreps (1998) noted.

The descriptions provided above of the collections housed in sultans' palaces are explicit enough: ceramic jars, gamelan orchestras, precious regalia articles, royal paraphernalia (throne, ritual umbrellas), bronze cannons, state insignia, and the like. Some are permanently exhibited to visitors, others are only visible during royal rituals, other still, as "private" collections, are stored away in back rooms.

Investigating the "collections" of ceramic jars and bronze or brass gongs of the tribal Kenyah Dayak in the remote interior, C. Kreps saw the Kenyah family rice barn as "functionally analogous to the museum both in terms of a place to store and protect valuable property and a structure that embodied conservation principles and techniques" (Kreps 2003: 132; see also 2005). Such collections, however, are never exhibited (Kreps 2006: 457), although individual items may serve as bridewealth goods or to pay ritual fines.

In both the sultanate's and tribal society's cases, these collections are pusaka - although there is no such term in Kenyah languages - and almost solely comprised of imported prestige articles, procured through trade with the coastal polities and following their example, at the exclusion of all types of locally manufactured objects. While they clearly are the result of an indigenous selection of "what is important," it may be argued that they hardly reflect the indigenous culture. In fact, they rather reflect the view of these societies' elite classes, the nobility and wealthiest families in both cases.

So, what we are considering here is "court arts", in its broadest sense, even in the case of Kenyah granary, not "folk arts and crafts." Contrasting the Mulawarman Palace and the Museum Balanga, then, is revealing enough. The Yogyakarta keraton or Buckingham and Versailles palaces are not meant for displaying folk arts. Where, then, should folk arts and crafts be displayed, 
both for regional cultural "conservation and development" and for the local younger generations' education? Will modern educated elites now in regional government spheres at some point come to recognize that a carved wooden spoon or a bamboo fishing basket is as important, if not more, than a Ming dynasty ceramic jar in the maintenance of regional cultural traditions, and start building ethnographic collections revealing daily-use artefacts and techniques?

It should be noted here, with Njoto (2015), that the concept of "heritage" translates differently as warisan in state agencies' legislation and publications and as pusaka among heritage NGOs, which promote the use of the latter word in their endeavor to protect the Indonesian heritage, as in their 2003 "Indonesian Heritage Year" (Tahun Pusaka Indonesia; Njoto 2015). While pusaka (from Sanskrit) and warisan (from Arabic) are close synonyms, the former tends to refer to heirloom as treasure, often with a spiritual component, whereas the latter appears more mundane. The choice of terms by either party, then, is probably not totally innocent (for discussions of pusaka, see Damais 1992, Soebadio 1992, Kreps 2003: 50-56, Njoto 2015).

To conclude with an open-ended question, it appears, twenty years after Kreps' (1994) remark, that what actually constitutes "culture" and how it should be developed, on both the national and regional levels, is and will continue to be a matter of debate in Indonesia.

\section{Acknowledgements}

My hearfelt thanks go to Mrs. Intan Mardiana (director of the National Museum, Jakarta), Hélène Njoto, Christina Kreps, Jean-Michel Chazine, and Antonio Guerreiro for their kind assistance, Hans Hägerdal for his permission to refer to his 2003 manuscript, Christopher Buyers (The Royal Ark) and Donald P. Tick (Kingdoms of Indonesia) for permission to use data from their Internet setups, and the reviewers for Archipel for their insightful comments. Since I have not been able to visit all the museums mentioned in this paper, I also extend the expression of my gratitude to various persons and organizations, most of which/whom I was unable to contact, for relevant information and illustrations found on their blogs or websites.

\section{References (Text)}

[Abbreviations: DM = Directorate of Museums (Jakarta); ICOM = International Council of Museums; RI = Republik Indonesia]

Adams, Kathleen M., 1999, "Identités ethniques, régionales et nationales dans les musées indonésiens," Ethnologie Française, 29 (3): 355-364.

Andini Perdana, 2011, "Museum dan Identitas: Museum La Galigo sebagai Media Komunikasi Identitas Budaya Sulawesi Selatan," paper, Seminar Towards Indonesian Postmodern Museums, 3 Maret 2011, Jakarta: Fakultas Ilmu Pengetahuan Budaya, Departemen Arkeologi, Universitas Indonesia. 
Asosiasi, 2013, Asosiasi Museum Indonesia [Obituaries of Ki Mohd. Amir Sutaarga] [http:// asosiasimuseumindonesia.org/component/search/?searchword=sutaarga\&searchphrase=all].

Bakker, L., 2008, "Politics or Tradition. Debating Hak Ulayat in Pasir," in Reflections on the Heart of Borneo, G.A. Persoon \& M. Osseweijer (eds), Wageningen: Tropenbos International, pp. 141-157.

Bilfaqih, H. Syed Ali Amin, 2006, Sekilas Sejarah Kesultanan Bulungan Dari Masa Ke Masa, Tarakan: C.V. Eka Jaya.

Chazine, J.-M., in press, "From Caves to Museums: Process and Sharing," in Framing Cultures: Visual Cristallizations and Cultural Transfers in the Use of Images in Anthropological Museums, L. Brutti (ed.), Marseille: Editions du CREDO.

Cribb, R., 2000, Historical Atlas of Indonesia, London: Curzon Press, Singapore: New Asian Library, Honolulu: University of Hawai'i Press.

Cribb, R., 2010, Digital Atlas of Indonesian History, Copenhagen: NIAS Press [booklet and cd-rom].

Damais, Soedarmadji, 1992, "Pusaka in Times of Change," in Pusaka. Art of Indonesia, Haryati Soebadio (ed.), Singapore: Archipelago Press, pp. 205-208.

DM, 1979/1980, Pedoman Pembakuan Museum Umum Tingkat Propinsi, by Moh. Amir Sutaarga, Jakarta: Direktorat Permuseuman, Proyek Pengembangan Permuseuman.

DM, 1989, Pedoman Pembakuan Sistem Penyelenggaraan Museum di Indonesia, Jakarta: Direktorat Permuseuman.

DM, 1989/1990, Pedoman Penyelenggaraan dan Pengelolaan Museum, by Amir Sutaarga, Jakarta: Direktorat Permuseuman, Proyek Pembinaan Permuseuman.

DM, 1995, Pedoman Klasifikasi Koleksi Museum Umum Negeri Provinsi, Jakarta: Direktorat Permuseuman.

DM, 1998, updated edition of DM 1979/1980 [not consulted].

DM, 2008, Pedoman Museum Indonesia, Gatot Ghautama \& Prioyulianto (eds), Jakarta: Direktorat Museum.

DM, 2009a, Ayo Kita Mengenal Museum, Jakarta: Direktorat Museum.

DM, 2009b, Bagaimana Mendirikan Sebuah Museum, Jakarta: Direktorat Museum.

DM, 2009c, Himpunan Peraturan Perundang-Undangan Republik Indonesia Tentang Museum, Jakarta: Direktorat Museum.

DM, 2011, Sejarah Permuseuman di Indonesia, Jakarta: Direktorat Permuseuman, 5 parts. [http://museumku.wordpress.com/sejarah-museum/].

Eisenberger, J., 1936, Kroniek der Zuider-en Oosterafdeeling van Borneo, Bandjermasin: Liem Hwat Sing.

Enthoven, J.J.K., 1903, Bijdragen tot de Geographie van Borneo's Wester-afdeeling, Leiden: Brill, 2 vol.

Fienieg, Anouk, 2007, Sejarah Sintang. The History of Sintang: A Collection of Books, Manuscripts, Archives and Articles, Amsterdam: KIT Publishers, KIT Bulletin No. 377 [not consulted].

Gazali Usman, Hj. A.,1994, Kerajaan Banjar. Sejarah dan Perkembangan Politik, Ekonomi Perdagangan dan Agama Islam, Banjarmasin: Lambung Mangkurat University Press.

Goenadi Nitihaminoto, Armeiny, \& Kosasih S.A., 1977, "Laporan Hasil Survai Kepurbakalaan di Propinsi Kalimantan Barat," Berita Penelitian Arkeologi, 6: 1-50.

Guerreiro, A., 2007, "Représentations architecturales et processus identitaires : le cas de l'Indonésie," Moussons, 11: 107-132.

Guerreiro, A., 2011, "Diversité culturelle et identités : les collections muséographiques en Indonésie et en Fédération de Malaysia," paper, Quatrième Congrès du Réseau Asie \& Pacifique, Paris, 14-16 Sept. 2011. [http://www.reseau-asie.com/userfiles/file/C04_ 
guerreiro_collections_museographiques.pdf].

Hägerdal, Hans, 2003, "Kerajaan-2 Indonesia: An alphabetic enumeration of the former princely states of Indonesia, from the earliest time to the modern period, with simplified genealogies and order of succession," unpubl. MS, Vaxjo (Sweden): University of Vaxjo.

Handleiding, 1884, Handleiding bij de beoefening der Land-en Volkenkunde van Nederlandsch Oost-Indië, Breda: Broese.

History, 2014, History of Museums and Cultural Institutions in Indonesia [http://www. reachinformation.com/define/List $\% 20$ of $\% 20$ museums $\% 20$ and $\% 20$ cultural $\% 20$ institutions\%20in\%20Indonesia.aspx].

Hitchcock, M., V.T. King, \& M. Parnwell, 2010, "Heritage tourism in Southeast Asia," in Heritage tourism in Southeast Asia, M. Hitchcock, V.T. King, \& M. Parnwell (eds), Copenhagen: NIAS Press, pp. 1-27.

ICOM, 1976, Museums in Indonesia, 1968-1976: Country report submitted by Muhammad Amir Sutaarga, Secretary National Committee ICOM Indonesia to the Asian Regional ICOM Assembly, Tehran, 13-18 November 1976, by M.A. Sutaarga, Jakarta: ICOM National Committee in Indonesia.

ICOM, 2010 [2002], "Country Paper of the Republic of Indonesia," by Indonesian Delegation, in Protection of Cultural Heritage in Southeast Asia. Workshop Proceedings, Hanoi, Vietnam, 9-13 April 2001, Amareswar Galla (ed.), Paris: Asia Pacific Organisation (ASPAC) of the ICOM \& Vietnam Ministry of Culture and Information, pp. 27-31. [Digital Version 2010].

Idwar Saleh, M., 1958, Sedjarah Bandjarmasin, Bandung: K.P.P.K., Seri Monografi.

Idwar Saleh, M., 1975, "Agrarian radicalism and movements of native insurrection in South Kalimantan (1858-1865)," Archipel, 9: 135-153.

Idwar Saleh, M., 1982/1983, Lukisan Perang Banjar, 1859-1865, Departemen Pendidikan dan Kebudayaan, Proyek Pengembangan Permuseuman Propinsi Kalimantan Selatan, Museum Negeri Lambung Mangkurat.

IS (Internet Sources), see below.

Kaltim Post, 2010, "HUT ke-1660 Kesultanan Kutai," Kaltim Post, 25 November.

Kemdikbud, 2013, Ministry of Education and Culture.

Klinken, G. van, 2006, "Colonizing Borneo: State-Building and Ethnicity in Central Kalimantan," Indonesia, 81: 23-49.

Klinken, G. van, 2007, "Return of the Sultans: The communitarian turn in local politics," in The Revival of Tradition in Indonesian Politics: The deployment of adat from colonialism to indigenism, J. Davidson \& D. Henley (eds), London: Routledge, pp. 149-169.

Kreps, C., 1994, "The Paradox of Cultural Preservation in Museums," Journal of Arts Management, Law, and Society, 23 (4): 292-306.

Kreps, C., 1998, "Museum Making and Indigenous Curation in Central Kalimantan, Indonesia," Museum Anthropology, 22 (1): 5-17.

Kreps, C., 2003, Liberating Culture: Cross-Cultural Perspectives on Museums, Curation, and Heritage Preservation, London: Routledge.

Kreps, C., 2005, "Indigenous Curation as Intangible Cultural Heritage: Thoughts on the Relevance of the 2003 UNESCO Convention," in Theorizing Cultural Heritage (A Fellowship Program at the Smithsonian Center for Folklife and Cultural Heritage Funded by the Rockfeller Foundation, Smithsonian Center for Folklife and Cultural Heritage), 1 (2): 3-8.

Kreps, C., 2006, "Non-Western Models of Museums and Curation in Cross-cultural Perspective," in A Companion to Museum Studies, Sharon Macdonald (ed.), London: Blackwell, pp. 457-472.

Kreps, C., 2012, "Museum Balanga as a Site of Cultural Hybridization," in Museum Objects: 
Experiencing the Properties of Things, Sandra H. Dudley (ed.), London: Routledge [not consulted].

Lombard, D., 1984, "Guide Archipel IV: Pontianak et son arrière-pays," Archipel, 28: 77-97.

Lontaan, J.U., 1975, Sejarah-Hukum Adat dan Adat Istiadat Kalimantan-Barat, Jakarta: Pemda Tingkat I KalBar.

Marryat, F.S., 1848, Borneo and the Indian Archipelago with Drawings of Costume and Scenery, London: Longman, Brown, Green, \& Longman.

Njoto, Hélène, 2015, "L'Invention du patrimoine indonésien," in Indonésie contemporaine, une révolution inachevée, R. Madinier (ed.), Paris: Les Indes Savantes \& IRASEC.

Picard, Michel, 1993, "Cultural Tourism in Bali: national integration and regional differentiation," in Tourism in South-East Asia, M. Hitchcock, V.T. King, \& M.J.G. Parnwell (eds), London: Routledge, pp. 71-98.

Picard, Michel, 1997, "Cultural Tourism, Nation Building, and Regional Culture: The Making of a Balinese Identity," in Tourism, Ethnicity, and the State in Asian and Pacific Societies, M. Picard \& R.E. Wood (eds), Honolulu: University of Hawai'i Press, pp. 181-214.

Pijnappel, J., 1968 [1860], "Kota Waringin in the 19th Century," in Hikajat Bandjar. A Study in Malay Historiography, by J.J. Ras, The Hague: Martinus Nijhoff, Appendix 1, pp. 618623.

RAI, 2012, The Royak Ark (Indonesia) [http://www.royalark.net/Indonesia/indon.htm].

Rath, Amanda, 1997, "Cultural Sublimation. The Museumizing of Indonesia," Explorations in Southeast Asian Studies, 1 (1). [http://www.hawaii.edu/cseas/pubs/explore/v1n1-art2.html].

Rees, W.A. van, 1867, De Bandjermasinsche Krijg van 1859-1863, Arnhem: Thieme.

RI, 1983, Ketetapan Majelis Permusyawaratan Rakyat Republik Indonesia Nomor: II/ MPR/1983 Tentang Garis-garis Besar Haluan Negara [Decree of the People's Congress of the Republic of Indonesia No. II/MPR/1983 on the Outline of the Plan Orientation].

RI, 2000, Peraturan Pemerintah Nomor 25 Tahun 2000 tentang Kewenangan Pemerintah dan Provinsi sebagai Daerah Otonom [Government Decree No. 25 of 2000 on the Authority of the State and of the Provinces as Autonomous Regions].

RI, 2004, Undang-Undang Nomor 32 Tahun 2004 tentang Pemerintahan Daerah [Law no. 32 of 2004 on Regional Government].

RI, 2005, Instruksi President Republik Indonesia Nomor 16 Tahun 2005 tentang Kebijakan Pembangunan Kebudayaan dan Pariwisata [Presidential Decree No. 16 of 2005 on Policy for the Development of Culture and Tourism].

RI, 2007, Peraturan Pemerintah Nomor 38 Tahun 2007 tentang Pembagian Kewenangan Pemerintah Pusat dan Daerah [Government Decree No.38 of 2007 on the Distribution of Authority between State and Regional Governments].

RI, 2009, Undang-Undang Republik Indonesia Nomor 10 Tahun 2009 Tentang Kepariwisataan [Law No. 10 of 2009 on Tourism].

RI, 2010, Instruksi President Nomor 1 Tahun 2010 Tentang Percepatan Pelaksanaan Prioritas Pembangunan [Presidential Decree No. 1 of 2010 on the Stepping up of the Implementation of the Priorities of Development].

Schwaner, C.A.L.M., 1853-54, Borneo. Beschrijving van het stroomgebied van den Barito en reizen ..., Amsterdam: P.N. Van Kampen, 2 vol.

SEK, 1989-90, Sekelumit Koleksi Museum Negeri Kalimantan Tengah, Palangkaraya: Proyek Pembinaan Permuseuman Kalimantan Tengah.

Sellato, B., 1998, "Modern architecture and provincial identity in Kalimantan," in Indigenous architecture in Borneo: traditional patterns and new developments, R.L. Winzeler (ed.), Williamsburg, VA.: Borneo Research Council, pp. 198-234.

Sellato, B., 2013, "Settlement, migration, and trade along river axes in Borneo," paper, Seventh EUROSEAS Conference, Lisbon, 2-6 July 2013. 
Sellato, B., in press, "Material Culture Studies and Ethnocultural Identity," in Borneo Studies: Past, Present and Future, V.T King, Wan Zawawi Ibrahim, \& Dk. Noor Hasharina Pg. Hj. Hassan (eds), Bandar Seri Begawan: Universiti Brunei Darussalam, Institute of Asian Studies, \& Springer, IAS Asia in Transition Series.

Sellato, B., n.d., Culture, History, Politics, and the Emergence of Provincial Identities in Kalimantan, unpubl. MS, dated 1991, with Postscript dated 2000, 30 p.

Soebadio, Haryati, 1992, "Introduction," in Pusaka. Arts of Indonesia, H. Soebadio (ed.), Singapore: Archipelago Press, pp. 15-16.

Soemadio, Bambang, 1987a, Sejarah Direktorat Permuseuman, Jakarta: Departemen Pendidikan dan Kebudayaan.

Soemadio, Bambang, 1987b, Petunjuk Tata Tertib di Museum Negeri Propinsi, Jakarta: Departemen Pendidikan dan Kebudayaan.

Sutaarga, Mohd. Amir, 1957, "Tugas Museum di Indonesia," Bahasa dan Budaja, VI (1): 3-14.

Sutaarga, Mohd. Amir, 1977, "Culture change and the role of museums in Indonesia," UNESCO, Regional Symposium on the Role of Museums in Changing Asian Societies.

Sutaarga, Ki Muhammad Amir, 1990, "Museology and Futurology," Jakarta: ICOM Indonesia, May 1990.

Suwedi Montana, 1994/1995, "Berita-berita Lama tentang Kotawaringin dan Inskripsi Jawa Kuna yang Unik di Kalimantan," Kebudayaan, 8: 15-21.

Tan, Heidi (ed.), 2010, Museum-Community Partnerships: The Role of ASEAN Museums in the 21st Century, Singapore: National Heritage Board.

Taylor, P.M., 1994a, "Introduction," in Fragile Traditions: Indonesian Art in Jeopardy, P.M. Taylor (ed.), Honolulu: University of Hawai'i Press, pp. 1-12.

Taylor, P.M., 1994b, "The 'Nusantara' Concept of Culture: Local Traditions and National Identity as Expressed in Indonesia's Museums," in Fragile Traditions: Indonesian Art in Jeopardy, P.M. Taylor (ed.), Honolulu: University of Hawai'i Press, pp. 71-90.

UNESCO, 1973, Cultural Policy of Indonesia, Paris: UNESCO.

UNESCO, 1985, Cultural Policy in Indonesia, Paris : UNESCO, Studies and Documents on Cultural Policies.

Vienne, M.-S. de, 2012, Brunei. De la thalassocratie à la rente, Paris: CNRS Editions.

Vita, \& T.M. Rita Istari, 1994, Situs Kotawaringin, Kecamatan Kotawaringin Lama, Kabupaten Kotawaringin Barat, Propinsi Kalimantan Tengah, report, Jakarta: Pusat Penelitian Arkeologi Nasional, Laporan Penelitian Arkeologi.

\section{Complementary references (Illustrations)}

Bock, C., 1882, The Head-Hunters of Borneo: a narrative of travel up the Mahakkam and down the Barito; also, Journeyings in Sumatra, London: Sampson Low, Marston, Searle, \& Rivington.

Buddingh, S.A., 1867, Neêrlands Oost-Indië. Reizen over Java, ...., Amsterdam, Wed. J.C. van Kesteren \& Zoon, $2^{\text {nd }}$ ed., 3 vols.

RIK, 1953, Republik Indonesia. Propinsi Kalimantan, n.p.: Kementerian Penerangan.

Werdmüller von Elgg, P.A.C.H.T.A., 1863, Twaalf schetsen van belangrijke punten uit het Rijk Bandjermasin, Borneo's Z. \& O. Kust: naar de natuur getekend [known under the title Schetsen uit Bandjermasin], no place, no publisher, portfolio $(34 \times 42 \mathrm{~cm})$.

\section{Internet sources (History, Palaces, Museums)}

http://en.wikipedia.org/wiki/List_of_museums_and_cultural_institutions_in_Indonesia 


\section{History}

Melayu Online: http://melayuonline.com/ind KOI, Kingdoms of Indonesia: http://kerajaan-indonesia.blogspot.fr/

\section{IS Banjarmasin}

http://id.wikipedia.org/wiki/Museum_Lambung_Mangkurat

http://kotawisataindonesia.com/wisata-museum-lambung-mangkurat/digital-camera/

http://www.indonesia-tourism.com/forum/showthread.php?520-Lambung-MangkuratMuseum-Banjarbaru-South-Kalimantan

http://onvacationtour.wordpress.com/2010/12/16/wasaka-museum/; http://www.wisatanesia. com/2010/09/museum-wasaka.html

\section{IS Kotawaringin}

http://id.wikipedia.org/wiki/Kerajaan_Kotawaringin;

http://kotawaringinbaratkab.go.id/pde/index.php?option=com_content\&view=article\&id= $90 \&$ Itemid $=56$

\section{IS Kutai, Museum Mulawarman}

http://www.kutaikartanegara.com/

http://museumku.wordpress.com/2010/04/24/museum-negeri-provinsi-kalimantan-timurmulawarman/;

http://kesultanan.kutaikartanegara.com/index.php?menu=Keraton_Kutai

http://museumku.wordpress.com/2010/05/13/museum-kayu-tuan-himba/

\section{IS Palangkaraya, Museum Balanga}

http://museumbalanga.comuf.com/museumbalanga.php

http://centralborneo.net/palangkaraya/museum-balanga/

\section{IS Pasir, Museum Sadurengas}

http://museumku.wordpress.com/2010/04/24/museum-sadurengas/; http://id.wikipedia.org/ wiki/Kesultanan_Pasir

\section{IS Pontianak}

http://disbudpar.kalbarprov.go.id/obyek-wisata/58-museum-negeri-pontianak.html; http:// www.pontianakweb.com/blog/kota-pontianak/item/35-museum-kalimantan-barat.html; http://www.museumindonesia.com/museum/44/1/Museum_Provinsi_Kalimantan_Barat_ Pontianak

\section{IS Sintang}

http://museumku.wordpress.com/2010/04/16/museum-kapuas-raya/;

http://asosiasimuseumindonesia.org/organisasi/anggaran-rumah-tangga/2-single-articles/270museum-dara-juanti.html;

http://www.culturalheritageconnections.org/wiki/Pusat_Kebudayaan_Sintang;

http://www.sintang.go.id/index.php?option=com content\&view=article\&id=228:museumkapuas-raya \&catid $=85$ :rokstories $2 \&$ Itemid $=4 \overline{4}$. 